University of Miami Law School University of Miami School of Law Institutional Repository

Articles

Faculty and Deans

2001

\title{
Crime Control and Feminist Law Reform in Domestic Violence Law: A Critical Review
}

Donna Coker

University of Miami School of Law, dcoker@law.miami.edu

Follow this and additional works at: https://repository.law.miami.edu/fac_articles

Part of the Law and Gender Commons, and the Law and Society Commons

\section{Recommended Citation}

Donna Coker, Crime Control and Feminist Law Reform in Domestic Violence Law: A Critical Review, 4 Buff. Crim. L. Rev. 801 (2001).

This Article is brought to you for free and open access by the Faculty and Deans at University of Miami School of Law Institutional Repository. It has been accepted for inclusion in Articles by an authorized administrator of University of Miami School of Law Institutional Repository. For more information, please contact library@law.miami.edu. 


\title{
Crime Control and Feminist Law Reform in Domestic Violence Law:
}

\author{
A Critical Review
}

Donna Coker*

The controversy about nation-wide implementation of mandatory arrest policies reflects the ambivalence with which feminists regard the police. On one hand, battered women's advocates want to hold the police accountable, as agents of the state, for carrying out the government's mandate to protect citizens. On the other hand, feminists realize that police often exercise their power in ways that reinforce the disadvantages already experienced by women, and in ways that reinforce the disadvantages experienced by members of poor and minority communities as well. ${ }^{1}$

We must frame this crisis the following way: state power ... simultaneously empowers and disempowers women. ${ }^{2}$

* Professor, University of Miami School of Law. Marc Fajer and Martha Mahoney provided particularly helpful comments on a later draft of this essay, for which I am very grateful. The comments of Peter Margulies, James Ptacek, and Lynne Henderson on a related book chapter draft were very useful in helping me formulate this article. I am also grateful for the comments and support of Deborah Weissman, Jonathan Simon, Zanita Fenton, and the participants of the conference, "Race, Class, Gender, and Ethnicity, Crime and Consequence: The Impact of Criminalization" at the University of North Carolina School of Law (March 2001). Special thanks to conference co-organizer Mary Lee Perry and the other U.N.C. students whose intellectual vision and organizational skills are truly impressive. Gregory McFarland and Stacey Bussel provided important research assistance. Of course, any mistakes in this article are my responsibility.

1. Anne Sparks, Feminists Negotiate the Executive Branch: The Policing of Male Violence, in Feminists Negotiate the State: The Politics of Domestic Violence 35, 35-36 (Cynthia R. Daniels et al. eds., 1997) [hereinafter Feminists Negotiate the State].

2. Laurie Naranch, Naming and Framing the Issues: Demanding Full Citizenship for Women, in Feminists Negotiate the State, supra note 1, at 20, 33. 


\section{INTRODUCTION}

The last several years have seen an explosion of domestic violence law reform. ${ }^{3}$ While significant changes have occurred in civil law provisions, ${ }^{4}$ much of the recent law reform has focused on a number of far-reaching changes in criminal law. ${ }^{5}$ This focus on criminal law

3. See generally Elizabeth M. Schneider, Battered Women: Feminist Lawmaking and the Struggle for Equality (2000) (describing feminist advocacy and lawmaking from the 1960s to the present day that resulted in reforms in laws and legal institutional responses to domestic violence).

4. For example, at least twenty-three states have now adopted child custody provisions with some form of presumption against child custody to a parent who commits domestic violence. See Ami S. Jaeger, A Review of the Year in Family Law: Century Ends with Unresolved Issues, 33 Fam. L.Q. 908 (2000). Every state has adopted special domestic violence protection order legislation. See Clare Dalton \& Elizabeth M. Schneider, Battered Women and the Law 498 (2001).

5. A number of states and municipalities have adopted strong domestic violence arrest and prosecution policies. See, e.g., Utah Code Ann. § 77-36-2.2 (Michie 1999) (stipulating that when a peace officer has probable cause to believe that an act of domestic violence has been committed, the peace officer shall arrest without a warrant any person that he has probable cause to believe has committed an act of domestic violence); Wis. Stat. \$ 968.075(2) (1998) (mandating that law enforcement personnel shall arrest and take a person into custody if the officer has reasonable grounds to believe the person has committed domestic abuse and either has a reasonable belief that continued abuse is likely or there is evidence of physical injury to the alleged victim). Some states have adopted specific domestic violence criminal statutes with penalties that exceed those for similar crimes against a non-intimate. See, e.g., Calif. Penal Code $\$ 273.5$ (2000) (the crime of infliction of injury on a spouse, cohabitee, or parent of child is committed whenever a person "willfully inflicts ... corporal injury resulting in a traumatic condition" and is a felony, punishable by "imprisonment... for two, three, or four years, or in a county jail for not more than one year, or by a fine of up to six thousand dollars...."). States have also adopted enhanced penalties when domestic violence commission is accompanied by certain aggravating factors such as the presence of a child. See, e.g., Alaska Stat. $\$ 12.55 .155$ (18)(C) (Michie 1998) (committing a domestic violence felony "in the physical presence or hearing of a child under 16 years of age who was, at the time of the offense, living within the residence of the victim, the residence of the perpetrator, or the residence where the crime involving domestic violence occurred" is an aggravating factor and may result in a term of imprisonment greater than the presumptive term). The Violence Against Women Act ("VAWA") passed in 1994 and the recently enacted Victims of Trafficking and Violence Protection Act of 2000 ("VAWA II"), have significantly changed federal criminal law, regarding domestic violence. See Violence Against Women Act of 1994, Pub. L. No. 103-322, 108 Stat. 1902 (codified as amended in scattered sections of 16 U.S. C., 18 U.S.C., and 42 U.S.C.); Victims of Trafficking and Violence Protection Act of 2000, Pub. L. No. 106-386, 
reform is the result of a confluence of factors. First, many advocates for battered women have urged a stronger criminal response, in part as a corrective for the history of profoundly inadequate and sometimes hostile response of the criminal justice system to domestic violence cases. ${ }^{6}$

Second, crime control politics makes criminal law a particularly attractive area of law reform. Politicians who oppose increased government spending on "social programs" have been happy to spend funds on "fighting crime." Fighting crime has political appeal to legislators

22 U.S.C. \$ 7101. VAWA enacted the following domestic violence related federal crimes: crossing a state line in violation of a restraining order (18 U.S.C. \$ 2262); crossing a state line to injure, harass or intimidate an intimate partner (18 U.S.C. $\$ 2261$ (a)(1)); forcing or tricking an intimate partner to cross a state line and intentionally committing injurious violence against the partner while doing so or as a result (18 U.S.C. $\$ 2261(\mathrm{a})(2))$. In addition, federal law requires anyone convicted of a domestic violence misdemeanor as well as anyone against whom a domestic violence restraining order has been issued to surrender all firearms and refrain from obtaining firearms that have been "shipped or transported" in interstate commerce. 18 U.S.C. $\$ 922(\mathrm{~g})(8)$.

In addition, VAWA included authorization for $\$ 120$ million in funds for state and Indian tribe efforts to promote arrest and prosecution in domestic violence cases and $\$ 800$ million for law enforcement training on domestic violence. 108 Stat. at 190-15.

6. See Susan Schechter, Women and Male Violence: The Visions and Struggles of the Battered Women's Movement 158 (1982) (noting that at the beginning of the movement, battered women complained that police refused to come when they were called, or they would side with the batterer, and they refused to arrest).

7. As one group of battered women's activists explains:

Women's organizations [against domestic violence] found a sympathetic ear in many legislative halls throughout the country. With such divisive and emotional issues as abortion, and economic issues such as pay equity, day care and affirmative action, legislatures found a "women's issue" that conservatives and liberals alike could agree upon: Beating women is wrong.

Mary E. Asmus et al., Prosecuting Domestic Abuse Cases in Duluth: Developing Effective Prosecution Strategies from Understanding the Dynamics of Abusive Relationships, 15 Hamline L. Rev. 115, 124 (1991); see also Dianne L. Martin, Retribution Revisited: A Reconsideration of Feminist Criminal Law Reform, 36 Osgoode Hall L.J. 151, 183 (1998):

A law and order agenda that increases surveillance and control of the underclass and directs justice resources toward street crime (and away from "crime in the suites"), while allying with apparently progressive issues such as reducing crime against women and increasing rights for crime victims has obvious public relations value.

Laureen Snider, Towards Safer Societies: Punishment, Masculinities and 
in part because it is one of the few concerns that reaches across differences in fractious American politics. ${ }^{8}$ As Jonathan Simon argues, citizen disillusionment with government's ability to provide for other aspects of communal life has strengthened this focus on crime control.9 The result, what Simon refers to as "governing through crime," 10 is increasing reliance on surveillance, control, punitive measures, and fear of crime to shape social behavior. ${ }^{11}$

Millions of dollars are now being spent on domestic violence criminal interventions. ${ }^{12}$ Battered women's advocates spend much of their time monitoring police and prosecutor response to battered women. ${ }^{13}$ There is nothing obvious or necessary about this allocation of dollars or human capital. Poor women are more vulnerable to repeat violence, ${ }^{14}$ yet relatively few dollars are allocated for measures that would render them less vulnerable such as transportation, or education and job training. ${ }^{15}$ Without

Violence Against Women, 38 The Brit. J. of Criminology 1, 9 (1998) ("Though oppositional [feminist] voices [against criminalizing policies] remained, calls for greater punitiveness were more easily heard than others, and coercive polices were eagerly adopted by governments seeking to legitimate agendas tightening control over underclass populations.").

8. See Jonathan Simon, Governing Through Crime, in The Crime Conundrum: Essays on Criminal Justice 171 (Lawrence Meir Friedman \& George Fisher eds., 1997).

9. Id.

10. See generally id.; Jonathan Simon, Governing Through Crime: Criminal Law and the Reshaping of American Government, 1973-1998 (forthcoming, 2001) manuscript at ch. 6 , on file with author).

11. Simon, supra note 8; see also Martin, supra note 7, at 173 ("fear [of crime] is a growth industry").

12. See text, infra note 18 (describing federal funding authorized through Violence Against Women Act I and II).

13. See infra pages $845-46$ (describing the role of battered women's advocates in monitoring police and prosecutors).

14. See infra note 70 (describing the research on the vulnerability of lowincome women to domestic violence); see also Donna Coker, Shifting Power for Battered Women: Law, Material Resources, and Poor Women of Color, 33 U.C. Davis L. Rev. 1009 (2000) (arguing for evaluating whether or not to adopt domestic violence laws, policies, or services by use of a material resources test that measures the likelihood of increasing battered women's access to material resources).

15. See Schneider, supra note 3, at 197. The failure of policy discourse to "link 
legal representation, women are unable to benefit from much of domestic violence law reform, yet women have no legal right to a state subsidy for an attorney ${ }^{16}$ and there are too few free lawyers for the number of domestic violence cases. ${ }^{17}$ Without adequate resources, women are unable to relocate and therefore, they are unable to escape the reach of controlling, violent ex-partners. Yet few dollars are allocated for emergency relocation and long-term housing. ${ }^{18}$ Women who are escaping well-funded or well-connected dangerous men need the equivalent of a witness-protection program (regardless of whether or not they testify in a criminal proceeding), but no such program exists.

Not only does a focus on crime control deflect attention from other anti-domestic violence strategies, crime control policies result in greater state control of women, particularly poor women. Further, under policies that do not allow victims to choose whether or not to arrest and prosecute their abuser, battered women are unable to leverage the potential of criminal prosecution in return for agreements from the batterer.

In the remainder of this article I turn to the two most

[domestic] violence to larger issues of gender" is illustrated by her experience:

In 1995 I was at the White House for the program establishing October as

Domestic Violence Awareness Month, at the same time that welfare 'reform' legislation was being debated in Congress. The White House domestic violence program emphasized criminalization reforms, but failed even to mention a link between welfare and violence.

Id.

16. See In re Smiley, 330 N.E.2d 53 (N.Y. 1975) (indigent wives in divorce actions have no constitutional right to have county provide counsel or to compensate counsel).

17. See, e.g., Bruce A. Green, Foreword: Rationing Lawyers: Ethical and Professional Issues in the Delivery of Legal Services to Low-Income Clients, 67 Fordham L. Rev. 1713, 1720 (1999) ("the funding of legal assistance for those who cannot afford it remains grossly inadequate to meet the need"); Peter Margulies, Representation of Domestic Violence Survivors as a New Paradigm of Poverty Law: In Search of Access, Connection, and Voice, 63 Geo. Wash. L. Rev. 1071, 1071 (1995) ("legal services programs have determined priorities through a skewed triage system that neglects domestic violence issues").

18. Recent federal legislation attempts to address this problem. See 42 U.S.C. $\$ 10401$ et seq. (2000) (authorizing funds for housing, transportation, counseling, child care services, case management, employment counseling, and other assistance for persons who are fleeing a situation of domestic violence). 
controversial criminal justice reforms in domestic violence cases: mandatory arrest ${ }^{19}$ and no drop prosecution ${ }^{20}$ policies. Mandatory arrest policies require that police arrest whenever there is probable cause to believe that a crime of domestic violence has occurred, even if the victim opposes arrest. ${ }^{21}$ No-drop prosecution policies generally require that prosecutors proceed with a domestic violence case, regardless of the desires of the victim. ${ }^{22}$ I refer to these policies collectively as mandatory policies.

These mandatory policies offer the battered women's movement some control over state response by increasing the likelihood that police and prosecutors will not reject battering cases. ${ }^{23}$ However, because these policies make irrelevant battered women's preferences regarding arrest

19. Mandatory arrest policies require that police officers responding to domestic violence calls arrest whenever there is probable cause to believe that a crime of domestic violence has occurred. If there is probable cause, arrest should occur even if the victim is opposed to arrest. See, e.g., Utah Code Ann. § 77-36-2.2 (Michie 1999) (stipulating that when a peace officer has probable cause to believe that an act of domestic violence has been committed, the peace officer shall arrest without a warrant any person that he has probable cause to believe has committed an act of domestic violence). Pro-arrest policies enact a presumption for arrest and require that whenever an officer fails to arrest on a domestic violence call, she/he must explain in writing the reason for the decision not to arrest. See, e.g., Fla. Stat. Ann. \$ 741.29(2)(b) (West 1997) ("If an arrest was not made, an indication by the law enforcement officer, in writing must be made, of the reasons why an arrest was not made.").

20. No-drop prosecution policies require that prosecutors refuse to drop charges against a domestic assailant whenever there is evidence that a crime of domestic violence took place, regardless of the victim's desires regarding prosecution. Cheryl Hanna describes "soft" and "hard" no-drop policies. Cheryl Hanna, No Right to Choose: Mandated Victim Participation in Domestic Violence Prosecutions, 109 Harv. L. Rev. 1849, 1863 (1996). Soft no-drop policies encourage victim cooperation with prosecution but do not resort to issuing subpoenas to victims or charging them with contempt of court when they fail to appear; some soft no-drop policies allow victims to drop charges if they first see a counselor or present their reasons to a court. With hard no drop policies, the prosecutor may subpoena victims as witnesses, pursue contempt charges if they fail to appear, and not allow victims to drop charges under any circumstances. Id.

21. See supra note 5 .

22. See supra note 20.

23. See, e.g., Evan Stark, Mandatory Arrest of Batterers: A Reply to Its Critics, in Do Arrests and Restraining Orders Work? 115, 127 (Eve S. Buzawa \& Carl G. Buzawa eds., 1996) ("The first reason for mandating arrest was to control police behavior."). 
and prosecution, ${ }^{24}$ mandatory policies limit the control of individual women. In addition, these policies operate in ways that may further state control of women, particularly women who are marginalized by race, class, immigrant status, or those whom state actors-police, courts, child protection workers-perceive to be "deviant." ${ }^{25}$ The dilemma for feminists is to develop strategies for controlling state actors-ensuring that the police come when called and that prosecutors do not trivialize caseswithout increasing state control of women. It is the dilemma of making domestic violence a public responsibility in the context of racist and classist public systems. ${ }^{26}$

\section{THE CONTEXT}

In her keynote address at a conference entitled, The Color of Violence: Violence Against Women of Color, ${ }^{27}$ Angela Davis provided the following challenge to feminist work against domestic violence:

We need an analysis that furthers neither the conservative project of sequestering millions of men of color in accordance with the contemporary dictates of globalized capital and its prison industrial complex, nor the equally conservative

24. See supra notes 19,20 (mandatory policies do not allow victims to determine whether or not arrest and prosecution takes place).

25. See infra section II at 821 .

26. See Donna Coker, Transformative Justice: Anti-Subordination Processes in Cases of Domestic Violence, in Restorative Justice and Family Violence: New Ideas and Learning from the Past (John Braithwaite \& Heather Strang eds., forthcoming 2001) (manuscript at 9, on file with author).

27. See Patricia Macias Rojas, Rebuilding the Anti-Violence Movement, 3 ColorLines (Fall 2000), available at www.arc.org/Clines.CLArchive/story 3303.html (describing the Color of Violence conference). The Color of Violence conference was organized by Andrea Smith, a graduate student and battered women's advocate. The conference, which took place at the University of California Santa Cruz campus, brought together activists, scholars, and attorneys from around the world to "strategize around the relationship among racism, colonialism, and gender violence in the lives and histories of women of color." Web posting announcing the conference, available at www.lmrinet.ucsb.edu/pipermail/reformanet/1999-September/004405.html. 
project of abandoning poor women of color to a continuum of violence that extends from the sweatshops through the prisons, to shelters, and into bedrooms at home. How do we develop analyses and organizing strategies against violence against women that acknowledge the race of gender and the gender of race? ${ }^{28}$

Like Davis, a number of scholars have raised concerns about the potential differential impact of mandatory policies on women and men of color. ${ }^{29}$ Arrest research suggests that arrests in domestic violence cases involve disproportionately high numbers of low-income men, ${ }^{30}$

28. Angela Davis, Keynote Address to Color of Violence Conference, recorded in Charles Brown, The Color of Violence Against Women (Oct. 25, 2000), available at http://csf.colorado.edu/soc/m-fem/2000/msg01004.htm. Davis also questions whether "a state that is infused with racism, male dominance, class-bias, and homophobia, that constructs itself in and through violence, [can] act to minimize violence in the lives of women of color." Id.

29. See Snider, supra note 7, at 9-10:

Anglo-American democracies over the 1970s and 80s revised law and policies on sexual and domestic assault, increased sanctions and introduced mandatory response, arrest and charging policies.... One result has been intensified immiseration of lower class women, visible minorities, native and aboriginal women. These are the women most vulnerable to contempt of court charges and to counter-charging practices, and least able to resist state action or find the resources to leave violent partners.

See generally Jenny Rivera, Domestic Violence Against Latinas by Latino Males: An Analysis of Race, National Origin, and Gender Differentials, 14 B.C. Third World L.J. 231, 245-46 (1994) (expressing concern about the effects of criminal policies in Latino communities); Cecelia M. Espenoza, No Relief for the Weary: VAWA Relief Denied for Battered Immigrants Last in the Intersections, 83 Marq. L. Rev. 163 (1999) (mandatory arrest policies result in increased numbers of arrests of non-citizen women who may then be rendered deportable under immigration law); Coker, supra note 14, at 10 (mandatory arrest policies increase vulnerability of poor women of color to state control); Barbara Fedders, Lobbying for Mandatory-Arrest Policies: Race, Class, and the Politics of the Battered Women's Movement, XXIII Rev. of L. \& Soc. Change 281 (1997) (the battered women's movement has failed to account for the differential impact of criminalizing policies on women of color).

30. See J. David Hirschel et al., The Failure of Arrest to Deter Spouse Abuse, $29 \mathrm{~J}$. Res. in Crime \& Delinq. 7, 9 (1992) ("Non-White, lower income women (under $\$ 7,500$ ) are more than twice as likely to report an incident to the police than are White, higher income (over $\$ 15,000$ ) females"); see also Ronet Bachman \& Linda E. Saltzman, Nat'l Crime Victimization Survey, Bureau of Justice Statistics, Special Report NCJ-154348, Violence Against Women: Estimates from the Redesigned Survey 4 (1995) (finding no statistically significant difference in 


\section{African American men, and Latino men. ${ }^{31}$ Despite evidence of disproportionate effects, little research has examined the}

domestic violence rates between black and white women or between Hispanic and non-Hispanic women, but finding that young women 19 to 29 years of age and women with annual family incomes under $\$ 10,000$ reported more domestic violence); Callie Marie Rennison \& Sarah Welchans, Bureau of Justice Statistics, Special Report NCJ-178247, Intimate Partner Violence 3 (2000) (reporting on the National Crime Victimization Survey findings). For a discussion of the importance of women's economic resources in their vulnerability to domestic violence, see generally Coker, supra note 14.

31. See, e.g., JoAnn L. Miller \& Amy C. Krull, Controlling Domestic Violence: Victim Resources and Police Intervention, in Out of the Darkness: Contemporary Perspectives on Family Violence 235, 239 (Glenda Kaufman Kantor \& Jana L. Jasinski eds., 1997) (assessment of data from three studies of domestic violence arrest finds that Blacks and Hispanics (studies' terms) are over-represented in the samples relative to their representation in the general population. In Milwaukee, Blacks were over-represented by a factor of 10.6 and Hispanics by a factor of 1.6; in Colorado Springs, Blacks were over-represented by a factor of 6.5 and Hispanics by 3.0 ; in Omaha, Blacks were over-represented by a factor of 9.3 and Hispanics by 1.9); see also, e.g., Richard A. Berk, What the Scientific Evidence Shows: On the Average, We Can Do No Better Than Arrest in Current Controversies on Family Violence 323, 331 (Richard J. Gelles \& Donileen R. Loseke eds., 1993) (43\% of the victims and $55 \%$ of the suspects were "ethnic minorities"); Michael Steinman, Coordinated Criminal Justice Interventions and Recidivism Among Batterers, in Woman Battering: Policy Responses 221, 224 (Michael Steinman ed., 1991) (study of a county with 96\% White, middle class population, but $32 \%$ of domestic violence arrests before adoption of pro arrest policy and 27\% of those after the adoption of the policy were of people of color); Ronet Bachman \& Ann L. Coker, Police Involvement in Domestic Violence: The Interactive Effects of Victim Injury, Offender's History of Violence, and Race, 10 Violence \& Victims 91, 98 (1995) ("II]ntraracial victimizations involving Black victims and Black offenders were almost two times more likely to result in an arrest compared to White-on-White victimizations") (emphasis added). But see Joan Zorza, Mandatory Arrest for Domestic Violence: Why It May Prove the Best First Step in Curbing Repeat Abuse, 10 Crim. Just. 2 (1995) (comparison of mandatory arrest rates of African Americans in Wisconsin found numbers smaller than their representation in the population (arrest rates of $1.3 \%$ compared with $3.9 \%$ of population) and, while African Americans made up about $10 \%$ of the domestic violence incident reports, they only accounted for $3.9 \%$ of the arrest reports). In some urban areas, women of color likely make up the majority of victim/complainants. See, e.g., Lisa Goodman et al., Obstacles to Victims' Cooperation with the Criminal Prosecution of Their Abusers: The Role of Social Support, 14 Violence \& Victims 427, 436 (1999) (study consisting of female victim complainants in domestic violence arrest cases in urban locale found that $90 \%$ of the women in the study were African American women); Judith Wittner, Reconceptualizing Agency in Domestic Violence Court, in Community Activisim \& Feminist Politics: Organizing Across Race, Class, and Gender 81, 87 (Nancy A. Naples ed., 1998) (a high percentage of women seen in Chicago's domestic violence court were women of color). 
impact of mandatory policies in low-income African American and Latino communities. ${ }^{32}$ Federal funding is earmarked for services for "underserved" battered women including racial and ethnic minority women, ${ }^{33}$ but few federal research dollars are available to study the impact on poor women ${ }^{34}$ and women of color of the criminal policies encouraged by federal funding legislation. ${ }^{35}$ The negative

32. See, e.g., Judith McFarlane et al., Characteristics of Sexual Abuse Against Pregnant Hispanic Women by Their Male Intimates, 7 Women's Health 739, 740 (1998) (quoting NIH Panel on Research on Antisocial, Aggressive, and ViolenceRelated Behaviors and Their Consequences as stating that: "An area of prime concern is the paucity of information on Hispanic, Native American, African American, and Asian involvement in aggressive and violent behavior, either as victims or as agents.").

33. See 42 U.S.C. $\S 10402(a)(C)$ (2000) (requiring state recipients of Family Violence Prevention funds to develop a plan "to address the needs of underserved populations, including populations underserved because of ethnic, racial, cultural, language diversity, or geographic isolation").

34. Much of domestic violence research fails to address the particular circumstances of poor women or women of color. See, e.g., McFarlane, supra note 32; Susan B. Sorenson, Violence Against Women: Examining Ethnic Differences and Commonalities, 20 Evaluation Rev. 123, 125 (1996) ( $"$ [R]elatively little empirical community-based research has investigated ethnic differences and similarities in violence against women in U.S. sub-populations. When investigated, groups typically are collapsed into White vs. non-White or Black vs. non-Black."). As Mary Ann Dutton writes:

Results of research including only Anglo American women cannot be assumed to apply to women of color, women living in poverty, or women whose native language is other than English. Research on battering and its effects for disenfranchised women, such as the homeless, the seriously and chronically mentally ill, define the life circumstances of these groups of battered women.

Mary Ann Dutton, Battered Women's Strategic Response to Violence, in Rethinking Violence Against Women 105, 118-19. (R. Emerson Dobash \& Russell P. Dobash eds., 1998).

35. See 42 U.S.C. $\$ 3796 \mathrm{hh}(\mathrm{C})(1)(\mathrm{A})(2000)$ (eligibility for "grants to encourage arrest policies" requires that the applicant unit of government certify that its laws "encourage or mandate arrests of domestic violence offenders based on probable cause that an offense has been committed."). Federal funds are also available for a limited number of states that qualify as "model" program states. See 42 U.S.C. $\$ 104.15$ (2000). To be designated as a model State, the state must adopt the following:

(1) a law that requires mandatory arrest of a person that police have probable cause to believe has committed an act of domestic violence or probable cause to believe has violated an outstanding civil protection order;

(2) a law or policy that discourages "dual" arrests;

(3) statewide prosecution policies that (A) authorize and encourage 
effects of mandatory policies on some poor women, and particularly on poor women of color, may be significant. ${ }^{36}$

This article examines domestic violence crime policy in the context of intersecting oppressive systems of race, class, and immigrant status. ${ }^{37}$ I have argued elsewhere that poor women and particularly poor women of color should be the focus for evaluating anti-domestic violence law and policies. ${ }^{38}$ These women are "sandwiched by their heightened vulnerability to battering, on the one hand, and their heightened vulnerability to intrusive state control, on the other. ${ }^{\text {"39 }}$ In essence, my argument is the reverse of the "rising tide carries all boats": Law and policy that is based on the experiences of poor women, and especially of poor women of color, is likely to result in reforms that benefit all battered women. But law and policy that is developed from the experiences of a generic category "battered women," is likely to reflect the needs and experiences of more economically advantaged women and white women, and is

prosecutors to pursue cases where a criminal case can be proved, including proceeding without the active involvement of the victim if necessary; and (B) implement model projects that include either (i) a "no-drop" prosecution policy; or (ii) a vertical prosecution policy; and (C) limit diversion to extraordinary cases, and then only after an admission before a judicial officer has been entered.

42 U.S.C. $\$ 10415$ (b)(1)-(3).

36. See section II, infra pages $821-41$ (discussing the risks to poor women of mandatory policies); see generally Espenoza, supra note 28 (describing the impact of mandatory arrest policies on immigrant women).

37. I agree with Claire Renzetti who writes:

Women differ in many ways, including,... their races and ethnicities, social classes, sexual orientations, ages, marital statuses, parenting statuses, and physical abilities or disabilities.... In considering how a specific policy affects women, feminists must analyze this intersectionality, and the analysis must be inclusive of the voices of diverse women.

Claire Renzetti, Connecting the Dots: Women, Public Policy, and Social Control, in Crime Control and Women 181, 187 (Susan L. Miller ed., 1998); see also Kimberle Crenshaw, Mapping the Margins: Intersectionality, Identity Politics, and the Violence Against Women of Color, 43 Stan. L. Rev. 1241 (1991).

38. See generally Coker, supra note 14 (advocating the adoption of a material resources test which evaluates the impact of any law, policy, or program on battered women's material resources and placing poor women and particularly poor women of color as the standard of measure).

39. Id. at 1011. 
unlikely to meet the needs of poor women and women of color.

In this article I discuss four areas in which mandatory policies present difficulties for feminist law reformers. The first area of difficulty is whether and how crime policies can prevent battering recidivism. The second is the role individual women's choices should play in determining the state's response to battering. The third is the degree to which mandatory policies are necessary in order to ensure that the state responds to domestic violence. The fourth is the degree to which mandatory policies are necessary or helpful in expressing the worth of battered women or society's rejection of battering.

In Section I, Controlling Men Who Batter: The Dilemma of Differential Deterrence, ${ }^{40}$ I examine the evidence that arrest acts as a specific deterrent to future violence, concluding that the best evidence is that arrest provides modest but generally short-lived deterrence. ${ }^{41}$ More importantly, arrest of unemployed men $^{42}$ or men who reside in socially disorganized neighborhoods ${ }^{43}$ may actually result in more incidents of violence than does separation of the parties or other police action. Studies of the effects on recidivism of "coordinated community response" programs are more encouraging. ${ }^{44}$ These programs include arrest and prosecution within a range of sanctions and services. Some studies find a deterrent effect

40. See infra page 814 .

41. See infra pages $814-15$.

42. See Lawrence W. Sherman et al., Crime, Punishment, and Stake in Conformity: Legal and Informal Control of Domestic Violence, 57 Am. Soc. Rev. 680,686 (1992) (noting that among married and employed batterers, arrest reduced subsequent violence, but among unmarried and unemployed batterers, arrest was associated with $53.5 \%$ increase in subsequent violence).

43. See Elizabeth Marie Marciniak, Community Policing of Domestic Violence: Neighborhood Differences in the Effect of Arrest (1994) (unpublished Ph.D. dissertation, University of Maryland) (on file with author) (analyzing Milwaukee data on the effects of arrest on domestic violence recidivism and finding that arrestees living in census tracts with high levels of female-headed households, families receiving welfare, poverty, high divorce rates, and high unemployment had higher domestic violence recidivism rates post-arrest).

44. See infra notes 60-61 and text accompanying. 
for those batterers who are subjected to the "full" coordinated treatment, ${ }^{45}$ while others find no deterrent effect. ${ }^{46}$

In Section II, Increasing State Control of Women: The Battered Women's Agency Dilemma, ${ }^{47}$ I examine the question of how much importance should be attached to individual women's preferences regarding mandatory policies. On the one hand, given our awareness of the batterer's potential to control the victim, ${ }^{48}$ it is not clear what weight should be given to women's preferences regarding criminal justice processing. On the other hand, mandatory policies increase state control of women, and this is particularly true for those women already vulnerable to state intervention. I examine three ways in which mandatory policies create a risk of greater state control of women: (a) mandatory policies increase the risk that battered women will be arrested for domestic violence; (b) mandatory policies increase the risk of unwarranted removal of children by state child protection agencies; (c) mandatory policies increase the risk that women involved, even peripherally, in criminal conduct will be prosecuted. The problem lies in reckoning both with the coercive power of the state and the coercive power of the abuser to control women's lives.

In Section III, Controlling the State: The Organizing Dilemma, ${ }^{49}$ I examine the importance of mandatory policies in ensuring that police and prosecutors protect battered women. Mandatory policies may aid in preventing the neglect that has amounted to state support for battering. Mandatory policies may also serve as an organizing tool for the battered women's movement in that they provide a legitimate rationale for movement advocates to have an

45. See infra note 61.

46. See infra note 60 .

47. See infra page 821 .

48. See Stark, supra note 23 , at 121 (coercive control describes "the systemic fusion of social and individual dominance that undermines the physical, psychological, or political autonomy of even the strongest, most aggressive and capable women.").

49. See infra page 841. 
ongoing role within the criminal justice system, and they offer a bright-line test around which to negotiate with police regarding their response to battered women. However, mandatory policies are sometimes implemented in areas with weak or non-existent battered women's advocacy organizations. Further, even where such organizations exist, they are not always representative of the interests of all battered women, particularly poor women and women of color.

In Section IV, Controlling the Message: The Dilemma of Expressing Social Disapproval, ${ }^{50}$ I examine the potential of mandatory policies to "send a message." Mandatory policies may "send a message" to society that battered women have worth, that battering is morally reprehensible, and that battering is a public rather than a private problem. However, the message of mandatory policies is likely to vary depending on the context in which it is "heard." I discuss several ways in which mandatory policies may have disproportionately negative effects and carry disproportionately negative meanings for some members of subordinated communities.

In the Conclusion, I argue that battered women's advocates must place women's material conditions at the center of our efforts. Increasing women's material resources will lessen the violence that women suffer. I suggest strategies for addressing the dual vulnerability of poor women to the violence of abusive men and to the violence of the state.

\section{CONTROLLING MEN WHO BATTER: THE DILEMMA OF DIFFERENTIAL DETERRENCE}

Most scholarly attention to mandatory policies lies in social science research regarding mandatory arrest. ${ }^{51}$ The National Institute of Justice ("NIJ") funded studies of

50. See infra page 849 .

51. See Janell D. Schmidt \& Lawrence W. Sherman, Does Arrest Deter Domestic Violence?, in Do Arrests and Restraining Orders Work?, supra note 23, at 43,45 (describing arrest replication studies in six cities). 
arrest effects in six major metropolitan areas, ${ }^{52}$ which together comprise a significant part of the research in this area. The NIJ studies were designed to test the specific deterrence effects of arrest against the effects of other police actions which included separating the couples, issuing a citation, and (in one study) issuing an arrest warrant for an absent suspect. ${ }^{53}$ Though the results of the studies varied somewhat across locations, the NIJ researchers generally concluded that arrest had at best a modest and short-lived deterrent effect. ${ }^{54}$ Lawrence Sherman's reevaluation of NIJ study data presents a greater challenge to the use of mandatory arrest policies. Sherman concluded that when unemployed men were arrested, their re-offending rates actually increased. ${ }^{55}$

Many studies point to factors other than arrest as strong predictors of recidivism. For example, several studies find that offenders who have prior histories of domestic violence or of other violent crimes, ${ }^{56}$ offenders who

52. Id.

53. Schmidt \& Sherman supra note 51 , at 45 (the Omaha study examined the deterrence effect of issuing an arrest warrant whenever the offender was absent when the police arrived and there was probable cause to believe he had committed a crime of domestic violence).

54. See Franklyn Dunford et al., The Omaha Domestic Violence Police Experiment-Final Report of the National Institute of Justice and the City of Omaha 34 (1989) (finding that both arrest measures and victim interviews found no significant difference in recidivism between offenders who were arrested and those separated or counseled); Hirschel, supra note 30 , at 13 (reporting no significant difference in recidivism between three treatment groups); Antony $M$. Pate \& Edwin E. Hamilton, Formal and Informal Deterrents to Domestic Violence: The Dade County Spouse Assault Experiment, 57 Am. Soc. Rev. 691, 694-95 (1992) (finding no statistically significant effect of arrest on the occurrence of a subsequent spouse assault, but when employed suspects were disaggregated from the whole, arrest acted as a significant deterrent for those employed); Lawrence W. Sherman et al., From Initial Deterrence to Long-Term Escalation: Short-Custody Arrest for Poverty Ghetto Domestic Violence, 29 Criminology 821 (1991) (short arrest had a substantial initial deterrent effect, but the effect ended at thirty days, and was followed by higher long-term recidivism effects than no arrest).

55. Sherman supra note 42 .

56. See, e.g., Robert C. Davis et al., The Deterrent Effect of Prosecuting Domestic Violence Misdemeanors, 44 Crime \& Delinq. 434, 438-39 (1998) ("Both prior misdemeanor convictions and battery arrests without conviction contributed independently to an increased risk of recidivism."); Eve Buzawa et al., Response 
are younger, ${ }^{57}$ and those who are unemployed ${ }^{58}$ are more likely to re-offend.

Studies of coordinated community intervention programs are more encouraging. Coordinated community interventions programs (CIP's) or coordinated community response programs involve a system-wide response to battering in which arrest and prosecution policies are coupled with batterer's treatment programs and immediate and significant outreach and advocacy for victims. ${ }^{69}$ While some researchers find no significant difference in specific deterrence for those subject to the full range of responses in a CIP, ${ }^{60}$ other research finds that the coordination and range of interventions results in lower rates of reoffending. ${ }^{61}$

to Domestic Violence in a Pro-Active Court Setting, Executive Summary (\#95-IJCX-0027) 24 (1999) (study of criminal justice response concludes that "the [domestic violence] offender's prior criminal history and age at first offense are the real keys to predicting re-offending ....").

57. See Carolyn M. West, Lifting the 'Political Gag Order': Breaking the Silence Around Partner Violence in Ethnic Minority Families, in Partner Violence: A Comprehensive Review of 20 Years of Research 184, 193 (Jana L. Jasinski \& Linda Meyer Williams eds., 1998) (domestic violence rates are highest for those under 30 years of age).

58. See generally Sherman, supra note 42 . The effect may be interactive, in that those suspects with a higher "stake-in-conformity" as measured by employment, stability in residence, socioeconomic status, and marital status, are more likely to be deterred by criminal interventions. Id.; see also Amy Thistlethwaite et al., Severity Dispositions and Domestic Violence Recidivism, 44 Crime \& Delinq. 388, 395 (1998) (the cumulative effect of stake-in-conformity variables in combination with jail and probation or a fine and probation was significantly to decrease incidents of re-abuse post-arrest; the most consistent findings were for length of employment, length of residence, and neighborhood SES in relation to the severity of punishment; contrary to prediction, being unmarried related to lower recidivism).

59. See generally Jeffrey L. Edleson, Coordinated Community Response, in Woman Battering: Policy Responses, supra note 31, at 203.

60. See, e.g., Buzawa et al., supra note 56, at 163, 165 (study of Quincy District Court's integrated system-wide response did not find differences in recidivism rates related to different intervention strategies including whether or not the defendant was prosecuted, whether or not prosecution resulted in subsequent court supervision, or whether or not the defendant completed a batterer's treatment program).

61. See, e.g., Christopher M. Murphy et al,, Coordinated Community Intervention for Domestic Abusers: Intervention System Involvement and Criminal Recidivism, 13 J. Fam. Violence 263 (1998) (finding that the cumulative 
There are far fewer studies of prosecution's effects on recidivism, but of those that exist, several find that no particular outcome of prosecution is significantly related to recidivism. ${ }^{62}$ David Ford and Mary Jean Regoli's study of prosecution effects compared cases in which women were allowed to drop charges with those cases where victims had no such choice. ${ }^{63}$ Regardless of the case outcome, there was a fifty percent reduction in violence in the six months following case resolution. ${ }^{64}$ The group of women who initiated charges and were permitted to drop, but who chose not to do so, experienced less recidivism than did women who were not allowed to drop charges. ${ }^{65}$ Women in the drop-permitted group who chose to drop charges, however, were at the greatest risk of re-abuse. ${ }^{66}$ The researchers conclude that "any intervention helps" ${ }^{\prime \prime 7}$ and recommend that women be allowed to "determine the

effects of successful prosecution, probation monitoring, and completion of court ordered counseling resulted in lower recidivism rates). But see Thistlethwaite et al., supra note 58 , at 396 (while length of jail sentences or probation were not significant predictors of recidivism, the combination of jail sentences and probation or a fine and probation correlated significantly with reduced recidivism compared to jail alone, fine alone, or probation alone); Steinman, supra note 31 (comparing arrest outcomes in period prior to adoption of coordinated response with outcomes after adoption of response and finding that arrest was associated with less re-offending in the latter period, but not in the first period); see also Richard M. Tolman \& Arlene Weisz, Coordinated Community Intervention for Domestic Violence: The Effects of Arrest and Prosecution on Recidivism of Woman Abuse Perpetrators, 41 Crime \& Delinq. 481, 491-92 (1995) ("recidivism drops progressively for those who complete the most protocol steps [of a coordinated community responsel....").

62. See, e.g., Davis, et al. supra note 56, at 441 (the researchers found no differences in recidivism in domestic violence misdemeanor cases that related to prosecution outcomes including nolles, dismissals, probation with treatment, and jail sentences).

63. David A. Ford \& Mary Jean Regoli, The Criminal Prosecution of Wife Assaulters: Process, Problems \& Effects, in The Impact of Police Laying Charges in Legal Responses to Wife Assault: Current Trends \& Evaluation 127, 157 (N. Zoe Hilton ed., 1993) (48\% of those allowed to drop the charges chose to drop the charges).

64. Id at 153 .

65. Id at 158 .

66. Id.

67. Id. at 157. 
prosecutorial track for court outcomes." ${ }^{68}$ We cannot know whether or not the fact that women chose to drop charges resulted in their revicitimiztion or whether the women who dropped made accurate assessments that prosecution would not make them any safer. However, other research suggests that battered women who oppose arrest and prosecution because they predict it will result in further violence are often accurate in their assessment. ${ }^{69}$

Little of this empirical research on deterrence examines whether arrest and prosecution results differ for poor women, women of color, or immigrant women. ${ }^{70}$ Anecdotal evidence suggests that each of these positions

68. Id. at 158. Even if arrest did provide a strong specific deterrence effect, we would still worry about the minority of women who were not made safer, particularly if those women opposed arrest because they believed (correctly, as it turned out) that their danger would increase (or at least not diminish) postarrest, or if they believed that arrest would have other negative effects on their life. For research that documents the accuracy of battered women's predictions of future violence, see Weisz et al., supra note 61 (battered women's prediction of future severe abuse significantly improved the accuracy of other risk assessment tools). Further, as I explain in greater detail later, even if arrest were to deter future violence, it may have corollary negative effects that out-weigh the benefits of deterrence for some women. See infra section II, pages 821-41.

69. See Buzawa, et al., supra note 56, at 19-20 (study of criminal justice intervention found that two groups of victims were most likely to report that criminal justice intervention made them more fearful or to believe that future criminal intervention would not be in their best interest: those involved with the most serious offenders and those whose offenders were new to the criminal justice system; those involved with the most serious offenders had "accurately determined that they were in greater danger of retaliation as a result of criminal justice intervention).

70. None of the originally published studies from the NIJ studies of arrest effects on recidivism examined racial differences among victims. However, a subsequent review of the data in North Carolina found that African American women were more likely to report abuse to the police than were White women. See Ira W. Hutchison \& J. David Hirschel, Abused Women: Help-Seeking Strategies and Police Utilization, 4 Violence Against Women 436 (1998); see also Bachman \& Coker, supra note 31 (review of National Crime Victimization Survey during 1987-1992 found that Black victims were more likely to report their victimization to the police than were others); Lawrence A. Greenfeld et al., Bureau of Justice Statistics Factbook, U.S. Dep't of Justice, NCJ-167237, Violence by Intimates: Analysis of Data on Crimes by Current or Former Spouses, Boyfriends, and Girlfriends 13 (Mar. 1998) (reporting based on the National Crime Victimization Survey found that Black women are more likely to report a violent victimization to the police than are other women). 
brings structural constraints that shape the effects of arrest in women's lives. ${ }^{71}$ Some research suggests that women's access to material resources makes a difference in their vulnerability to recurring violence. ${ }^{72}$ For example, research that compared two groups of battered women found that those who met twice weekly with an advocate who assisted them in gaining access to community resources, ${ }^{73}$ reported significantly less abuse two years

71. See section II, infra pages $821-41$.

72. Women's access to material resources is a critical factor in determining their vulnerability to domestic violence. See generally Coker, supra note 14; James Ptacek, Battered Women in the Courtroom: The Power of Judicial Responses 22-24 (1999) (reviewing data from various studies and finding that domestic violence is more prevalent and more severe in low-income families); Angela Browne \& Shari S. Bassuk, Intimate Violence in the Lives of Homeless and Poor Housed Women: Prevalence and Patterns in an Ethnically Diverse Sample, 67 Am. J. Orthopsychiatry 261, 263 (1997) (citing National Family Violence Survey finding that husband's unemployment significantly predicted prevalence of husband-to-wife violence); Richard J. Gelles, Through a Sociological Lens: Social Structure and Family Violence, in Current Controversies On Family Violence 31, 33 (Richard J. Gelles \& Domileen R. Loseke eds., 1993) (stating that domestic violence occurs in all social and economic groups, but risk is greatest for those that are poor, that are married to men that are unemployed or that hold low prestige jobs); Angela M. Moore, Intimate Violence: Does Socioeconomic Status Matter?, in Violence Between Intimate Partners: Patterns, Causes, and Effects 90, 96 (Albert P. Cardarelli ed., 1997) (reviewing data regarding correlation of low socio-economic status and domestic violence and concluding that "[w]omen on the lower end of the economic scale are at greater risk of victimization than their counterparts at the higher levels."). This research does not support the view that domestic violence is a problem only for low-income families. See Ptacek, supra, at 20-21 (describing "class myth" that domestic violence occurs only in low-income families).

73. See Cris M. Sullivan \& Deborah I. Bybee, Reducing Violence Using Community-Based Advocacy for Women with Abusive Partners, $67 \mathrm{~J}$. Consulting \& Clinical Psychol. 43 (1999). The groups were matched in terms of demographics, including race, age, employment status, and severity of violence. Each group contained roughly the same number of women co-habitating with their abuser and women separated from their abuser. See id. Forty-five percent of the experimental group were African American women, $42 \%$ were EuroAmerican women, $7 \%$ were Latina, $2 \%$ were Asian American or American Indian. Id.; Cris M. Sullivan et al., After the Crisis: A Needs Assessment of Women Leaving a Domestic Violence Shelter, 7 Violence \& Victims 267, 269 (1992). The advocates met with the women twice weekly for ten weeks and assisted the women in gaining access to educational resources, legal assistance, employment, services for their children, housing, child care, transportation, financial assistance, health care, and social supports. Id. at 51. The advocate worked with the women for an average of 6.4 hours per week. Id. at 45 . The advocates were 
later. $^{74}$ The researchers believe that what made the advocacy program succeed was that participants, not advocates, guided the direction of the intervention, and the "activities were designed to make the community more responsive to the woman's needs, not to change the survivor's thinking or belief system."

In summary, while some research suggests that arrest and prosecution act as specific deterrents to future violence, most of the research paints a more complicated picture. First, some men who batter are more likely to be deterred by formal sanctions than are others. It is the interaction between criminal sanctions and the personal and social characteristics of abusers that determines the risk of recidivism, rather than the nature of criminal justice intervention, per se. Second, providing advocacy and assisting battered women in locating resources and services is an important and often overlooked variable in recidivism. Third, in evaluating the risk of re-abuse, it may be particularly important to give deference to battered women's assessments of their risk. Finally, given the limited research, we cannot know the extent to which these outcomes are representative of those experienced by poor women, women of color, or immigrant women. ${ }^{76}$

trained under graduate students who received school credit for their work. They were supervised weekly. Id.

74. One out of four women in the experimental group experienced no abuse during the twenty-four month follow up, while this was true for only one out of ten women in the control group. Id. at 51. The women who met with advocates also reported significantly less psychological abuse and depression and significantly higher improvement in quality of life and level of social supports than did those in the control group. Id. at 45. Only the difference in psychological abuse scores did not reach statistical significance. Id. at 48 . Both groups of women reported that their quality of life and their social support networks had improved and that the abuse had decreased; however the experimental group reported significantly higher outcomes. Id. The interviews to determine improvement were conducted by trained interviewers who were not the advocates, thus decreasing the likelihood of responses that are skewed upwards. Of course, this is still a danger with this kind of research.

75. Id. at 51. The project was based on the assumption that "survivors were competent adults capable of making sound decisions for themselves." Id.

76. See Dutton, supra note 34, at 118-19. Dutton writes:

Results of research including only Anglo American women cannot be 


\section{INCREASING STATE CONTROL OF WOMEN: THE BATTERED WOMEN'S AGENCY DILEMMA}

Martha Mahoney writes that "[a]ll work with subordinated people confronts... the challenge of analyzing structures of oppression while including an account of the resistance, struggles, and achievements of the oppressed." A number of feminist scholars propose using the term "agency" to describe this resistance and achievement. The concept of agency rests on the realization that autonomy for subordinated persons is always partial, contingent, and emerging. ${ }^{78}$ Kathryn Abrams's conception of agency has "a political dimension to... [the] process of recognizing and reflecting on the influence on social norms .... [that] make it more difficult for women to develop independent self-conceptions."79 Thus, agency requires a collective endeavor because it is "only through conversation with others who have confronted similar feelings that a woman becomes aware that her selfconception does not simply reflect her own shortcomings, but is a function of views and expectations that are

assumed to apply to women of color, women living in poverty, or women whose native language is other than English. Research on battering and its effects for disenfranchised women, such as the homeless, the seriously and chronically mentally ill, and immigrants, is necessary to capture the unique contextual influences that define the life circumstances of these groups of battered women. Id.

77. Martha R. Mahoney, Victimization or Oppression? Women's Lives, Violence, and Agency, in The Public Nature of Private Violence: The Discovery of Domestic Abuse 54, 59 (Martha Fineman \& Roxanne Mykitiuk eds., 1994) [hereinafter The Public Nature of Private Violencel; see also Elizabeth M. Schneider, Particularity and Generality: Challenges of Feminist Theory and Practice in Work on Woman-Abuse, 67 N.Y.U. L. Rev. 520, 527 (1992) (describing the false dichotomous descriptions of battered women as either victims or agents).

78. See generally Elizabeth Schneider, Describing and Changing: Women's Self-Defense Work and the Problem of Expert Testimony on Battering, 9 Women's Rts. L. Rep. 195 (1986); Kathryn Abrams, From Autonomy to Agency: Feminist Perspectives on Self-Direction, $40 \mathrm{Wm}$. \& Mary L. Rev. 805 (1999); Kathryn Abrams, Changing the Subject: Agency, Law \& Feminist Legal Theory (forthcoming 2001) (manuscript at 825, on file with author) Thereinafter Changing the Subject].

79. Abrams, Changing the Subject, supra note 78 , at 826 . 
instilled socially." 80

In contrast to these conceptions of agency, law often places human character at polar extremes: either all-agent or all-victim. ${ }^{81}$ As Mahoney writes, "agency and victimization are each known by the absence of the other: you are an agent if you are not a victim, and you are a victim if you are in no way an agent." 82 Elizabeth Schneider recognized early the problem this presented for battered women who must articulate both their ability to be agents (for example, in child custody proceedings) and their victimization (for example, in protection order hearings). ${ }^{83}$

To some extent, this false dichotomy of victimization versus agency plagues discussions of mandatory policies, but even when that is not the case, giving effect to women's agency in the context of criminal responses to domestic violence has presented difficulties for feminist law reformers. Some abusive men intimidate, harass, threaten, and physically force women to abandon criminal charges. ${ }^{84}$ This fact is central to feminist arguments for mandatory policies. The concern is that giving battered women a "choice" whether to pursue criminal charges means giving the choice to batterers. ${ }^{85}$ In addition, ongoing humiliation

80. Id. at 827-28. Susan Williams argues for a somewhat similar "narrative" concept of autonomy. Susan H. Williams, A Feminist Reassessment of Civil Society, 72 Ind. L.J. 417, 430 (1997). The narrative process requires that a woman "work with her own experiences and the stories, values, and concepts that are available to her in whatever culture(s) she inhabits ...." Id. Williams argues that to be autonomous, individuals must have a capacity for self-knowledge, have self-trust or self-esteem, and must have the ability to appreciate others evaluative standards. Id. at 441.

81. See, e.g., Schneider, supra note 77, at 548-49:

We now alternate between visions of the battered woman as agent-as cause or provocateur of the battering-and the battered woman as helpless victim.... [P]ortraying women solely as victims or solely as agents is neither accurate nor adequate to explain the complex realities of women's lives.

82. Mahoney, supra note 77 , at 64 .

83. See generally Schneider, supra note 77.

84. See Machaela M. Hoctor, Domestic Violence as a Crime Against the State:

The Need for Mandatory Arrest in California, 85 Cal. L. Rev. 643, 687 (1997).

85. Ellen L. Pence, Some Thoughts on Philosophy, Coordinating Community 
and assaults on personhood may encourage some women to believe that they are partially responsible for their partner's violence ${ }^{86}$ which may compromise their ability to judge their own best interest. ${ }^{87}$ Thus, simple accounts of women's agency_-"if a woman wants to live in a violent relationship, it is her choice"88_fail to account for the level of coercion and restraint operating in battered women's lives.

On the other hand, the batterer is not the only agent of violence and coercion that women face. State mechanisms of control act powerfully in women's lives, particularly in the lives of poor women. Women risk increasing state control in their lives when they negotiate with the state for assistance against the private domination of their partners or ex-partners.

The danger is that feminist law reformers will both overestimate the state's power to do good and underestimate the power of the state to do harm. Further, women's decisions whether or not to support criminal intervention are often related to whether or not they can afford to prioritize prosecution over other more immediate concerns such as food, employment, and childcare. Thus, the second danger is that feminist law reformers will overlook the importance of women's material resources in the calculus of whether or not state intervention is likely to do harm or good.

Responses to Domestic Violence: Lessons from Duluth and Beyond 25 (Ellen L. Pence \& Melanie F. Shepard eds., 1999); Hoctor, supra note 84, at 687 ("[b]ecause batterers have such overwhelming control over their victims[,] [when victims were allowed to drop chargesl ... batterers, in effect, were being given control over the disposition of their own criminal case.").

86. See Dennis P. Saccuzzo, How Should the Police Respond to Domestic Violence: A Therapeutic Jurisprudence Analysis of Mandatory Arrest, 39 Santa Clara L. Rev. 765, 781 (1999) (battered women may believe that they are responsible for their abuser's violence).

87. See, e.g., id.; Lenore E.A. Walker, Battered Women's Syndrome and SelfDefense, 6 Notre Dame J.L. Ethics \& Pub. Pol'y 321, 330 (1992) (describing the effects of learned helplessness).

88. Hanna, supra note 20 , at 1874 (quoting a judge's response to a battered woman's request that he drop criminal charges against her abuser). 


\section{A. Overestimating the Power of the State to Do Good}

I identify two ways in which feminist support for mandatory policies may overestimate the power of the state to assist battered women. The first is to overestimate the power of the state to protect women. As I discuss in Section I, the equivocal data regarding the effects of arrest and prosecution on batterer recidivism does not warrant strong confidence that criminal intervention will prevent further abuse. In addition, this focus on the protective power of the state fails to account for the number of ways in which women successfully stop battering. The second way in which feminist support for mandatory policies may overestimate the state's power to do good is found in those arguments that focus on future changes in society brought about by crime control policies. This confidence in the ability of changes in crime policy to bring about social change is unwarranted.

1. Overestimating the Protection the Criminal Justice System Affords

Cheryl Hanna, in reflecting on her experiences as a domestic violence prosecutor, describes a case in which the judge dismissed charges at the complainant's request. ${ }^{89}$ When Hanna next encounters this woman, the woman has a broken nose, severe bruising, and has lost forty pounds from the stress. ${ }^{90}$ Women often experience renewed violence, despite the promises of batterers to reform, ${ }^{91}$ but the point of Hanna's story is not merely that domestic violence sometimes escalates. The implicit message of the narrative is that the woman would have been safe (or safer)

89. Id. at 1875.

90. Id.

91. Laura Crites \& Donna Coker, What Therapists See that Judges May Miss: A Unique Guide to Custody Decisions When Spouse Abuse is Charged, The Judge's Journal, at 9, 10, Spring 1998 (batterers sometimes promise never to abuse again). 
if only the judge had refused to drop charges. ${ }^{92}$ Hanna sets up a dichotomy: Women can be allowed to make the "wrong" decision (against prosecution) or the state can protect their interests in stopping the violence (and proceed with prosecution). This unfairly stacks the deck in favor of mandated prosecution policies.

Any choice a battered woman makes is, to some extent, playing the odds. ${ }^{93}$ Narratives like Hanna's rest on two implicit and questionable assumptions. The first is that cooperation with the system is more likely to increase a woman's safety than is non-cooperation. The second assumption regards the relevant universe of choice: $A$ woman chooses either to be wholly cooperative with

92. Hanna makes this implicit presumption clear when she later in the same article concludes: "[I]f a battered woman does not cooperate, ... and the case results in dismissal, she is likely to be beaten again.... [T] f the prosecution is successful, she may never be victimized by anyone again. ..."). Hanna, supra note 20 , at 1895 . This is a common form of narrative in the literature that supports no-drop prosecution. See, e.g., Donna Wills, Domestic Violence: The Case for Aggressive Prosecution, 7 UCLA Women's L.J. 173, 179 (1997). Wills relates the story of a woman who was killed by her estranged husband. When he was first arrested for assaulting her the woman begged that the prosecutor drop the charges. When the prosecutor refused to drop charges, the victim made herself "unavailable" for trial and the charges were dismissed for lack of evidence. The woman did not report her abuser's subsequent assaults, including one in which he tried to run her over with a car. She did, however, call the police when he grabbed their infant child and put her in the car unrestrained. The police arrested her husband, but he was released quickly when his family posted bail. The same day he purchased a gun and killed her. Wills understands the moral of this story to be that the victim was wrong to want charges dropped in the first instance: "many battered women fail to see that criminal intervention can assist in the shared goal of getting their abuser to stop the violence." Id. However, like Hanna's narrative, Wills's story does not prove her conclusion. There is no evidence that this victim would have been made safer had she cooperated with prosecution the first time. In fact, when she did cooperate with criminal intervention (when her husband kidnapped her child), her husband was released quickly and she was murdered. Further, the prosecutor's refusal to drop charges when she requested that she do so may explain why the victim did not report her husband's later attacks.

93. See Donna K Coker, Heat of Passion and Wife Killing: Men Who Batter/Men Who Kill, 2 S. Cal. Rev. L. \& Women's Stud. 71, 106-07 (1992) (some battered women are "entrapped in a web of the [abuser's] ... making, in which every action she takes to protect herself threatens to reinforce his view that she's attacking him; thus, actions taken to increase her safety also have the potential to increase her danger."). 
prosecution or she chooses to be wholly uncooperative with prosecution.

The assumption that the criminal justice system offers the best chance of increasing a woman's safety overstates the efficacy of the system in stopping the violence while simultaneously understating the importance of the availability of women's other resources. As described in Section I, the evidence for the deterrent value of arrest and prosecution is equivocal. Prosecution (or other state intervention) is no guarantee that the violence will stop. ${ }^{94}$ A woman who opposes prosecution is taking a calculated risk, as is the woman who actively pursues prosecution. Neither she, nor the judge or the prosecutor, can know with certainty which action will result in less violence. The problem is not that the batterer's coercion is not real, but rather that it is not always clear that the criminal justice system offers a better alternative.

The assumption that women are safest when they cooperate with prosecution also ignores the stories of the women who are successful in stopping the violence in their lives. ${ }^{95}$ Lee Bowker's study of women who solved their domestic violence problem found that women employ a number of strategies which may or may not include criminal justice intervention, and that some women are successful at stopping the violence and resuming their relationship with their formerly abusive partner. ${ }^{96}$

But "[w]omen's successes at ending violence are virtually invisible." ${ }^{\text {97 }}$ Criminal justice system actors are unlikely to see (again) the women who accurately assess that non-cooperation is in their best interest. ${ }^{98}$ Prosecutors and police officers will not see the women who elect noncooperation in return for concessions from the batterer and

94. Hanna elsewhere acknowledges that this is the case. Hanna, supra note 20 , at 1871 ("state intervention into women's lives does not necessarily promote their equality, safety, or well-being.").

95. See generally Lee H. Bowker, Beating Wife-Beating (1983).

96. Id.

97. Mahoney, supra note 77 , at 76 .

98. See id. 
who do not experience subsequent abuse. They will not see the women who reunite with a formerly abusive partner and no longer experience abuse.99 In addition, they may not see the women for whom arrest and prosecution resulted in increased violence. Recent research regarding the effects of a pro-arrest policy found that two groups of women were the most likely to be strongly opposed to mandatory arrest. ${ }^{100}$ The first were those who had experienced minor violence and who accurately predicted that they were not in danger. ${ }^{101}$ The second were those women who were in extreme danger from very violent partners and who predicted accurately that arrest and prosecution would not make them any safer..$^{102}$

The assumption that the universe of choice is limited to total cooperation with prosecution versus noncooperation may also be unwarranted. Women attempt to strategically use formal system resources such as prosecution. ${ }^{103}$ As Judith Wittner concludes from her study

99. Mahoney relates the story of a woman who, with help from her church, ended her abusive husband's violence. The church assisted her in negotiating for a requirement that the husband work with a men's prayer group, attend counseling, and take a sabbatical from his campus ministry position. The couple separated initially, but reconciled after two years and the woman reported no further abuse. Id. 76-77. A battered women's counselor in the Navajo Nation related her own personal story that is quite similar. She and her abusive partner separated for two years. During the separation period he began alcohol treatment and counseling and she returned to school and became financially independent. They reconciled and there has been no renewed violence. See Donna Coker, Enhancing Autonomy for Battered Women: Lessons from Navajo Peacemaking, 47 UCLA L. Rev. 1, 68 (1999).

100. Buzawa, et al., supra note 56 .

101. Id.

102. Id.

103. See, e.g., David A. Ford, Prosecution as a Victim Power Resource: A Note on Empowering Women in Violent Conjugal Relationships, 25 Law \& Soc'y Rev. 313,314 (1991) (noting that women may desire to use prosecution as a power resource to negotiate more safety and more control in their lives); Adele Harrell \& Barbara E. Smith, Effects of Restraining Orders on Domestic Violence Victims, in Do Arrests and Restraining Orders Work?, supra note 23, at 214, 219 (of the $40 \%$ of women studied who did not return for a permanent restraining order, 64\% reported that the temporary order had stopped their partner's abuse at least temporarily); Wittner, supra note 31 (women used specialized domestic violence court strategically to gain greater control over their lives, but did not necessarily complete legal processes). 
of a domestic violence court, some women "[want] the right to tell their stories in public, authority to participate in the determination of punishments, and freedom to fashion courses of legal action suited to themselves rather than to arbitrary demands of the judicial system."104 Others studies find that some battered women successfully use the threat of criminal prosecution to gain much needed leverage in the relationship. ${ }^{105}$

The process used by prosecutors may be an important determinant of whether or not women are able to successfully use the power the state in this fashion. Linda Mills argues that mandatory policies "rob battered women of an important opportunity to acknowledge and reject patterns of abuse." Mills proposes that prosecutors adopt the perspective of the survivor of domestic violence ${ }^{107}$ and

104. Wittner, supra note 31 , at 83 . Wittner notes of legal professionals in a dedicated domestic violence court:

[S]o convinced were [legal professionals]... that adherence to court procedures offered the only route to safety and protection, they seldom entertained the notion that certain complainants had other, more fruitful agendas in involving the law. So committed were they to a legal timetable that they viewed a woman's repeated use of the court as proof that her failure to follow through to the end of a case doomed her to continued victimization.

Id. at 89 .

105. Carolyn Hoyle \& Andrew Sanders, Police Response to Domestic Violence: From Victim Choice to Victim Empowerment, 40 Brit. J. Criminology 14, 23 (2000). Hoyle and Sanders' interviews with battered women found that some opposed prosecution because "the arrest achieved the changes which the victim sought in her partner's behaviour." Id. It is important not to overstate this point, however. Fear of retaliation was the most common reason women gave for opposing prosecution. Id. at 24 . Nonetheless, as the authors note, "different women have different aims and needs ...." Id. at 24.

106. Linda Mills, Killing Her Softly: Intimate Abuse and the Violence of State Intervention, 113 Harv. L. Rev. 550, 555 (1999). By mandating processes that the woman may not yet be ready to endorse, mandatory policies push women to align with their batterer and view the state as an enemy. Id.

107. Id. at 605 ('strategies should begin 'where the battered woman is' rather than where others 'expect' her to be"); id. at 589 (forcing a victim to testify may "cause her to realign with [the batterer]... rather than face the state's violence."). For a contrary argument, see Hanna, supra note 20, at 1552 (criticizing battered women's advocates because they want prosecutors to be both therapist and trial attorney, "[y]et, supporting the victim emotionally and holding the batterer criminally responsible are often conflicting goals."). 
hear "[a battered woman's] story on her terms and in ways that take into account her particular circumstances."

\section{Overestimating the Ability of Criminal Justice Reforms to Effect Future Social Change}

A separate agency problem is presented by arguments that women should be coerced to cooperate with prosecution not because it is in their best interest, but because it will benefit other women ${ }^{109}$ or future women. ${ }^{110}$ Hanna argues that even though prosecution against a woman's wishes may harm some women, limits on the autonomy of individual women is justified because prosecution is good for "women overall."111 Similarly, Ellen Pence compares battered women to African Americans who first integrated public schools.

We often liken this dilemma to that of civil rights activists trying to desegregate lunch counters, schools, and buses in Jim Crow states. When the first children walked into

108. Mills, supra note 106 , at 605 . Mills's opposition to mandatory policies is part of a more ambitious project to re-define the role of professional response to a victim-centered approach. In her book, The Heart of Intimate Abuse, Mills argues that not only criminal justice system actors, but child protection and health care system actors must adopt an empowerment model for working with battered women. Linda G. Mills, The Heart of Intimate Abuse: New Interventions, in Child Welfare, Criminal Justice, and Health Settings (1998). Hanna and Mills have a fundamental difference in perspective in that Hanna seeks to answer a policy question without challenging the current institutional framework within which the question is framed, while Mills seeks to remake that system. See, e.g., Hanna, supra note 20, at 1873 (noting that in any policy debate, someone has to decide, Hanna writes that "[i]n the criminal justice system, the prosecutor maintains discretion as to which cases are pursued. The question, then, is not who decides, but how should the decision be made.").

109. Hanna, supra note 20 , at 1870 .

110. See Pence, supra note 85 , at 33 .

111. Hanna, supra note 20 , at 1870 ("Although removing a woman's right to choose whether to prosecute may undermine her autonomy, such an infringement on her liberty is necessary to protect women overall."). Mills is particularly critical of this rationale for mandatory policies: "In my view, individual survivors should not be exploited-even for the laudable goal of eliminating gender oppression-especially when those survivors are likely to be women of color and, more often than not, exploited in other contexts by the white male and female majorities." Mills, supra note 106, at 593. 
previously all-White schools, those children did not get a better education. We have all seen the news stories of those tense days when African American children walked through crowds of screaming, threatening White adults. They entered empty classrooms. The victory was for those who followed. When the civil rights movement used these children to change a basic inequality in society, it secured an agreement from the government to call out the National Guard to protect them. The challenge to those of us who argue that we need to criminalize domestic violence, even when the victim wants us to back off, is to put into place safeguards equivalent to the National Guard's protection of Black children in desegregating Southern schools. ${ }^{112}$

These arguments reflect a certainty about the potential for future social change through criminal justice reform that is both unwarranted and dangerous. This kind of unwarranted certainty in the efficacy of social change through criminal justice reform facilitates ignoring today's harm because of a belief that it will be better in the future.

\section{B. Underestimating the Power of the State to do Harm}

Mandatory policies make battered women more vulnerable to state control. This vulnerability is particularly true for women who are marginalized by their race, ethnicity, class, or immigrant status. In this section, I examine three ways in which mandatory policies increase the risk of state control of women. The first risk occurs when battered women are themselves arrested for domestic violence. The second risk of increased state control occurs when criminal justice intervention results in unwarranted intervention from the state child protection agency. The third risk is for women who are involved, even peripherally, in criminal activity, much of which is related

112. Pence, supra note 85 , at 33 . To compare battered women draftees with integrationist activists, turns agency on its head. Even if this analogy were accurate, Pence fails to explain why coercing individuals in ways that are harmful to them personally is justified because it is done in the name of progress. See Mills, supra note 106, at 593. 
to their experience of battering.

\section{When Battered Women are Arrested for Domestic Violence}

The first set of risks for increased state control flow from the increased risk that battered women will be arrested. When mandatory and pro-arrest policies are adopted, more women are arrested for domestic violence. ${ }^{113}$ Strong anecdotal evidence suggests that most of the women arrested are victims of battering who are acting in selfdefense or who are responding to a pattern of abuse. ${ }^{114}$

Arrests of battered women present serious collateral risks that go beyond the threat of criminal punishment. For example, conviction for domestic violence can result in the deportation of a non-citizen. ${ }^{115}$ Recent immigration law reform allows the Attorney General to waive deportation in the case of battered women who can prove that they are "not the primary perpetrator of violence in the relationship"116 and that they were "acting in selfdefense."17 The difficulty with this standard is that many women who are violent in response to ongoing battering

113. See Joan Zorza \& Laurie Woods, National Center on Women and Family Law, Mandatory Arrest: Problems and Possibilities 16 (1994) (noting that "advocates report a widespread increase in arrests of women when police departments adopted tougher arrest policies"); L. Kevin Hamberger \& Theresa Potente, Counseling Heterosexual Women Arrested for Domestic Violence: Implications for Theory and Practice, 9 Victims \& Violence 125, 126 (1994) (finding that after Wisconsin instituted mandatory arrest, arrests of women increased by twelve- fold compared to two-fold increase in arrests of men).

114. See Zorza \& Woods, supra note 113; Hamberger \& Potente, supra note 113 , at 108. Margaret E. Martin, Double Your Trouble: Dual Arrest in Family Violence, $12 \mathrm{~J}$. of Fam. Violence 139, 147 (1997) (study of stratified sample of all family violence cases disposed in criminal courts in Connecticut during the first six months of 1988 found that $33 \%$ of the adult intimate arrests were dual arrests).

115. See 8 U.S.C. $\$ 1227(a)(E)(i)$-(ii) (1994 \& Supp. II 1996) (stipulating that classes of deportable aliens include those convicted of domestic violence, stalking, or violation of protection orders, and crimes against children). For a discussion of this problem, see generally Espenoza, supra note 29 .

116. 8 U.S.C. $\& 1227(a)(1)(7)$.

117. 8 U.S.C. $\& 1227(a)(1)(7)(I)$. 
may not meet the legal requirements for self-defense in a particular incident. For example, Cecelia Espenoza relates the story of Paula, a battered immigrant woman from Mexico, who received support from Lideras Campensinas. ${ }^{118}$ Paula, determined not to take her husband's abuse any longer and, with a baseball bat in hand, told him to leave the home. ${ }^{119}$ He tried to return three times. Each time, he left after Paula threatened him with the bat. ${ }^{120}$ In many jurisdictions, Paula's actions would render her criminally liable for domestic violence assault and thereby subject her to mandatory arrest. ${ }^{121}$ Since Paula was not in immediate danger when she threatened her husband, it is not clear that she would meet the self-defense requirements for the waiver of deportation.

In addition to immigration consequences, battered women who are arrested often lose the protection otherwise afforded by special domestic violence legislation. For example, evidence of an arrest, even if the women are not charged, is sufficient in many states to prevent them from benefiting from child custody laws that disfavor a violent parent. ${ }^{122}$

118. Espenoza, supra note 29, at 196-97 (citing Pamela Warrick, A Life of Their Own: They Have Been the Victims of Abusive Men-Husbands, Bosses-And Have Spent Years Laboring in the Fields, But Farm Worker Women Are Learning How to Fight for Their Rights, L.A. Times, June 7, 1996, at E1). Prior to the new waiver legislation, some women were rendered deportable. For example, consider the story of Maria Sanchez, related in a Washington Post story. Maria's husband came home drunk, pinned her on the couch, and began beating her. Maria bit his back. Her husband called the police and Maria was arrested. She tried telling the police that he had been beating her again and that she was defending herself but, unlike her husband, she didn't speak English and the police spoke no Spanish. When she went to court, Maria signed a form, printed in English, that waived her right to counsel and entered a guilty plea to misdemeanor assault. Maria had no understanding of the forms she was signing and the court's unqualified interpreter was no help. At the time of the story, Maria faced deportation proceedings, even though her husband had a prior record for domestic violence. Philip P. Pan, Victimized Woman Faces Deportation, Wash. Post, Feb. 20, 2000, at A1.

119. Id.

120. Id.

121. See supra note 5 (discussing mandatory arrest provisions).

122. See, e.g., Ala. Code $\S 30-3-131$ (Michie 1998) (providing for a rebuttable presumption that it is not in the best interest of the child to be placed in the 


\section{Battered Women and Child Protection Services}

The second set of risks created by mandatory policy flows from the interaction of mandatory policies with the actions of other institutions of state control. The police response may open a "Pandora's box... of other institutional responses." ${ }^{23}$ The most important such interaction is that of child protection systems. Several changes in child protection laws and policies have increased dramatically the number of child abuse investigations founded solely or primarily on the basis that a child's parent is the victim of intimate abuse. ${ }^{124}$ Some police departments have developed policies that require officers to report to child protection services every case in which a child is present at a domestic violence call. ${ }^{125}$ In addition, child protection organizations have broadened

custody of the perpetrator of family violence); 13 Del. Code Ann. $\S 705 \mathrm{~A}$ (1999) (same); Nev. Rev. Stat. Ann. 125C.230 (Michie 1998 \& Supp. 1999) (same); see also, e.g., Zorza \& Woods, supra note 113, at 24 (a battered woman who is arrested may "lose the advantage meant to be given to her... in a custody dispute.").

123. Family Protection and Domestic Violence Intervention Act of 1994: Evaluation of the Mandatory Arrest Provisions, Third Interim Report to the Governor and the Legislature 55 (Oct. 2000) (available from the State of New York, Division of Criminal Justice Services) (on file with the author) [hereinafter New York Evaluation of Mandatory Arrest Provisions].

124. See Somini Sengupta, Tough Justice: Taking a Child When One Parent is Battered, N.Y. Times, July 8, 2000, at A1 (describing New York City case in which children were removed because the mother's estranged husband punched her in the face while one child slept and the other was at school); interview with Stacey Dougan, former Director, Greenberg Traurig/Florida Coalition Against Domestic Violence Alliance, in Miami, Fla. (describing similar trend in Florida); Deborah Epstein, Effective Intervention in Domestic Violence Cases: Rethinking the Roles of Prosecutors, Judges, and the Court System, 11 Yale J.L. \& Feminism 3, 35-37 (1999) (even though mother immediately reported her husband's abuse of their daughter, obtained a restraining order against him that denied him access to the child, and aided his prosecution, the state attorney filed failure to protect charges against the mother).

125. See Telephone Interview by Stacey Bussel with Captain Drew Kirkland, Portland, Oregon Police Department (June 6, 2000). Captain Kirkland explained that officers are required to report the presence of children at any domestic violence call. The police department's records division forwards the officer's domestic violence reports in which children were present to the state child and family protection agency. Id. 
dramatically the definition of child abuse to include residing in a home in which domestic violence takes place. ${ }^{126}$ Children are removed even when the violence was a one-time occurrence, and even when the children did not witness the violence. ${ }^{127}$ The statements of rural battered women in New York State capture the problem of the intersection between child protection and mandatory policies:

It does more damage to call the police... The call to the police opened up so many doors. Then I had three different services watching me and with the kids. Child protective put me at risk for losing my children; they said, next time they'll take the kids! I always thought the police were there to help me. I would never call them again. ${ }^{128}$

126. See, e.g., Sengupta, supra note 124 (describing cases in New York City). 127. See id.

128. New York Evaluation of Mandatory Arrest Provisions, supra note 123, at 55. Women reported the following additional reasons for being dissatisfied with the police response: The police treated the victim with disrespect; the police refused to do anything, including look for a hiding suspect; they did not take the violence seriously. Id. at 54-55. Those who were satisfied with the police reported the following reasons for their satisfaction: The police were respectful to them; the police arrested the abuser. Some indicated that having the arrest decision taken out of their hands contributed to their satisfaction with the police response. Id. at 54 . An additional dilemma faces both proponents and opponents of mandatory policies. What little research exists that examines women's preferences, suggest that they differ and, to some extent, those differences are mutually exclusive. Some women want the criminal justice system to decide whether or not to prosecute; others want the authority to decide for themselves. See Edna Erez \& Joanne Belknap, In Their Own Words: Battered Women's Assessment of the Criminal Processing System's Responses, 13 Violence \& Victims 251, 260 (1998) (survey of women who were victim complainants in criminal domestic violence cases found that $68 \%$ thought victims should be allowed to drop charges, $15 \%$ thought they should not be allowed to drop charges, and 21\% expressed no opinion; $49 \%$ thought women should be forced to testify, $39 \%$ did not know). This presents a problem for proposals that women be allowed to decide whether or not they want the prosecutor to decide. See, e.g., Mills, supra note 106, at 578 ([the battered woman] should decide whether she would like to pursue [arrest and prosecution]... or whether she would prefer state representatives to pursue arrest and prosecution on her behalf, and without her active participation.") This option appears to be precisely the burden some women seek to avoid, while other women desire to have the option. 
He beats me and I get [Child Protective] Services dropping in on me three times a week. Meanwhile, no one is getting him help. ${ }^{129}$

Like so many other forms of state intervention, child protection intervention is a double-edged sword. When a child is in danger of serious harm, temporary removal of the child from the home may be the only safe course, but there are a number of problems with the way in which current child welfare policy works in cases of domestic violence. Child welfare workers and courts frequently blame battered women for their children's exposure to violence. ${ }^{130}$ This blame suggests that the mother could control or could avoid the batterer's violence. In many cases, neither is true. Battering is often unpredictable: Women are beaten for "failure" to have the proper demeanor, for "failure" to prepare the "right" meal, for "failure" to desire sex at the "right" times. ${ }^{131}$ Separation is no guarantee of safety. Most of the women who are killed and most women who are seriously assaulted by an intimate are separated at the time of the attack. ${ }^{132}$ Thus, separation often requires careful planning. "Despite welldocumented evidence that battered women are at greater risk of harm from their abusers during separation, the child protection system's traditional approach has been to require battered women to leave their abusers immediately

129. New York Evaluation of Mandatory Arrest Provisions, supra note 123, at 55.

130. See V. Pualani Enos, Prosecuting Battered Mothers: State Laws' Failure to Protect Battered Women and Abused Children, 19 Harv. Women's L.J. 229 (1996) (describing case in which, despite the abuser's severe battering of the mother, the court blamed the mother for her "inability to terminate relations with the abuser and found that her inability to provide her child with a violence-free environment demonstrated a 'willful failure' to meet the demands of her parental responsibilities, thereby justifying the termination of her parental rights.").

131. See Coker, supra note 93 , at 85 ("Abusive men blame their violence on complaints about the woman: she's a bad housekeeper; she doesn't show the men the proper deference; she's verbally aggressive; she's a poor mother.... [S]he's not sexually responsive enough; she is-or desires to be-sexually unfaithful.").

132. See id. 93, at 71 n.2 (describing homicide research); see also Martha $R$. Mahoney, Legal Images of Battered Women: Redefining the Issue of Separation, 90 Mich. L. Rev. 1, 49-50 (1991) (describing the dangers of "separation assault.") 
or face the loss of their children." ${ }^{133}$ Separation also requires resources. Women who separate need money for new housing-first and last month rent plus deposit, new childcare arrangements, new school enrollments, and a new job. Many women must make these arrangements while using inadequate and unreliable public transportation. When women separate they often require a restraining order. They must then distribute copies of the order, along with a picture of the abuser, to the children's schools and childcare providers and to the security personnel at their work site.

The failure of child protection workers to understand the dangers of separation and the importance of women's material resources to their safety results in a failure to provide the resources and support that battered women most require. ${ }^{134}$ Women are often coerced into signing "voluntary" plans that include agreements to participate in such services as parenting classes and battered women's support groups ${ }^{135}$ but are not given assistance with the resources needed to separate safely. ${ }^{136}$

In addition, child protection workers often believe stereotypes regarding battered women that make invisible their acts of agency. ${ }^{137}$ They are presumed to have mental health problems that make them likely to "choose" batterers. ${ }^{138}$ Frequently these stereotypes of battered

133. Hon. Cindy S. Lederman et al., The Nexus Between Child Maltreatment and Domestic Violence: A View from the Court, 2 Center for Families, Child. and the Cts. J. 129, 129 (2000).

134. Id.

135. See Amy Sinden, 'Why Won't Mom Cooperate?': A Critique of Informality in Child Welfare Proceedings, 11 Yale J.L. \& Feminism 339 (1999) (describing the coercion involved in "voluntary" plans). My own experience in coordinating a battered women's program in Honolulu, Hawaii, was that women were often unable to find employment and their safety was compromised because they were required to attend so many "services."

136. See Jane C. Murphy, Legal Images Of Motherhood: Conflicting Definitions From Welfare "Reform," Family, and Criminal Law, 83 Cornell L. Rev. 688, 741 (1998).

137. See Mahoney, supra note 77, at 71 (describing case where woman's parental rights were terminated because a psychologist testified that she might enter a second violent relationship).

138. See id. 
women intersect with and reinforce race- and class-based stereotypes. Poor women and particularly poor African American women are far more likely to be the subject of charges of child neglect ${ }^{139}$ than are other women. "In child welfare cases, where the individual is pitted against the vast power and resources of the state, the power imbalance is extreme. And in the vast majority of cases, the fact that the parent is female, poor, uneducated, and nonwhite, exacerbates this inherent power disparity."140

\section{When Battered Women Are Involved in Criminal Activity}

Aggressive criminal intervention also threatens to increase state control of battered women who are involved, even peripherally, in criminal activity. ${ }^{141}$ Battered women's criminal activity is often connected to their abuse. For example, battering partners coerce women into engaging in crimes that involve illegal drugs or prostitution, ${ }^{142}$ women

139. See, e.g., Gelles, supra note 72, at 34 ("[p]oor and minority children are more likely to be correctly and incorrectly reported for child abuse, whereas white and middle-and upper-class families are much less likely to be correctly and incorrectly reported for abuse") (emphasis in original); Dorothy E. Roberts, Is There Justice in Children's Rights?: The Critique of Federal Family Preservation Policy, 2 U. Pa. J. Const. L. 112, 125-26 (1999). Roberts notes:

The injustice of the American foster care system ... stems... from the large number of children removed from their homes. The class and race dimensions of foster care magnify this problem-virtually all of the parents who lose custody of their children are poor, and a startling percentage are black.... Moreover, once black children enter foster care, they remain there longer, are moved more often, and receive less desirable placements than white children.

140. Sinden, supra note 135 , at 385 .

141. As Dianne Martin notes, "bad' mothers [and] 'bad' girls ... are never real victims [in the crime control discourse,] ... [rather] they are subjected to ever more invasive controls and surveillance...." Martin, supra note 7, at 158 .

142. See Beth Richie, Compelled to Crime: The Gender Entrapment of Battered Black Women 114-16 (1996) (describing manner in which batterers force women into illegal sex work); id. at 120-23 (recounting manner in which batterers forced women to engage in theft); id. at 123-27 (finding that battered women developed drug dependencies in order to establish deeper connections with their drugabusing partners). Kathleen Daly's study of women's pathways to felony court in New Haven, Connecticut documents two pathways that underscore the 
sell drugs or sex in order to earn money to fund an escape from battering partners, ${ }^{143}$ and women use illegal drugs to dull the physical and emotional pain of abuse. ${ }^{144}$ The danger of identification, arrest, and conviction for drug related offenses is much higher for women of color and particularly for African American women who live in heavily policed "drug zones."145 Draconian drug laws with severe mandatory minimum sentences increase dramatically the risks associated with detection. ${ }^{146}$ Further, mandatory sentencing regimes make it more difficult for women to make traditional arguments about their care taking responsibilities ${ }^{147}$ or their abusive

connection between abusive partners, drug use, and drug related crimes. Kathleen Daly, Gender Crime and Punishment 58 (1994) (finding that women's pathways to felony court include being in relationships with violent men and being associated with boyfriends, mates, or family members who use or sell drugs).

143. See, e.g., Richie, supra note 142 , at 126 (white woman arrested on drug charges explains that she sold drugs in order to get an apartment: "I tried working, but my husband found out, beat me up, and took my money ... . I was starting to save enough [through drug sales] to move out.").

144. See, e.g., Cynthia Chandler et al., Community-Based Alternative Sentencing for HIV-Positive Women in the Criminal Justice System, 14 Berkeley Women's L.J. 66, 78 (1999) ("Abuse survivors may also develop harmful drug addictions attempting to self-medicate to forget or to recover from the assault."); Mary Ann Dutton, Empowering and Healing the Battered Woman: A Model for Assessment \& Intervention 64 (1992) ("Substance abuse among battered women functions as a means of self-medicating the distress and dysfunction (caused by the battering] ... by reducing immediate anxiety and enhancing the numbing effect, thus blocking out the experience of distress and emotional pain."); Richie, supra note 142 , at 125 (describing an interview with woman whose boyfriend brought her morphine in order to dull the pain from broken bones and other injuries caused by his beatings).

145. See Stephanie R. Bush-Baskette, The War on Drugs as a War Against Black Women, in Crime Control and Women, supra note 37, at 113 (the increase in Black women's incarceration rates is largely due to the "war on drugs"; Black women are a greater percentage of the female prison population than Black men are of the male prison population).

146. See generally Michael Tonry, Race and the War on Drugs, $1994 \mathrm{U}$. Chi. Legal F. 25 (1994) ("Reagan and Bush administration crime bills year after year increased penalties and extended mandatory minimum sentences for additional drug crimes, a conservative Sentencing Commission toughened penalties even more ... and prison populations tripled from 1980 onwards ....").

147. See Myrna S. Raeder, Gender and Sentencing: Single Moms, Battered Women, and Other Sex-Based Anomalies in the Gender-Free World of the Federal Sentencing Guidelines, 20 Pepp. L. Rev. 905 (1993) (some courts recognize single 


\section{partner's coercion. ${ }^{148}$}

The risks associated with arrest for drug activity are not limited to the criminal law consequences. Women who are arrested risk losing custody of their children. ${ }^{149}$ They may also be barred for life from receiving welfare benefits ${ }^{150}$ and their student financial aid may be compromised, ${ }^{151}$ thus ensuring their continued economic dependence on male partners and their continued vulnerability to further abuse. ${ }^{152}$

parent responsibilities as a reason for a downward departure from federal sentencing guidelines, while others do not). Raeder documents the gender disparity in refusal to recognize childcare responsibilities: far more women than men are single parents. In addition, the impact of refusal to see single parenting as a reason for downward departure may affect African American women more than white women because single parenting is much more prevalent among African American women. Id. at 950. Compare United States v. Brand, 907 F.2d 31 (4th $\mathrm{Cir}$.), cert. denied, 498 U.S. 1014 (1990) (defendant's situation as a single parent whose incarceration would result in her children's placement with strangers was not extraordinary, and therefore does not warrant a downward departure in sentencing), with United States v. Pena, 930 F.2d 1486 (10th Cir. 1991) (upholding downward departure for a single mother of a two month old and a sixteen year old daughter who also cared for the daughter's infant child).

148. See Raeder, supra note 147 , at 741-42 (describing the way in which courts have interpreted sentencing guidelines with regard to an abuser's coercion of a woman offender).

149. See Lisa Maher \& Richard Curtis, Women on the Edge of Crime: Crack Cocaine and the Changing Contexts of Street-Level Sex Work in New York City, in Criminology at the Crossroads: Feminist Readings in Crime and Justice (Kathleen Daly \& Lisa Maher eds., 1998) 110, 110 ("The expanded interface between the criminal law and women's lives afforded by the 'war on drugs' has been accompanied by increased administrative regulation which, in labeling these women 'unfit mothers,' has sought to remove their children, their welfare and Medicaid benefits and their housing-usually in that order.").

150. Welfare reform legislation adopted in many states renders someone with a felony drug conviction permanently disqualified from receiving Temporary Assistance for Needy Families (TANF) funds. See 21 U.S.C. \& 862(a) (1994) (requiring states to opt out of the drug conviction restriction). Twenty-two states retain the ban. See Amy E. Hirsch, The World Was Never a Safe Place for Them": Abuse, Welfare Reform, and Women with Drug Convictions, 7 Violence Against Women 159, 159 (2001).

151. See 20 U.S.C. $\$ 1091$ (1994) (financial aid eligibility is temporarily suspended for the first offense of possession of a controlled substance and for the first offense of sale of a controlled substance. The third possession or the second sale offense results in indefinite suspension. However, eligibility may be restored if the student completes a drug rehabilitation program that complies with certain criteria.).

152. See Debra S. Kalmus \& Murray A. Strauss, Wife's Marital Dependency 


\section{Women's Access to Material Resources Shapes Their Experiences with Criminal Interventions}

Rather than the result of batterer intimidation or persuasion, women's cooperation with mandatory policies, particularly with prosecution, is often a product of their access to material resources and the quality of their interactions with actors in the criminal justice system. ${ }^{153}$ Cooperation with prosecution often requires women to take time off from work, to acquire transportation and childcare, or to make other sometimes costly and difficult arrangements. ${ }^{154}$ Thus, women who have family or friends who will watch the children, help them with chores, or provide transportation or emergency loans, are more likely to cooperate with prosecution than women who do not have access to these informal sources of tangible support. ${ }^{165}$ As I discussed previously in this article, women's lack of access to material resources can make them more vulnerable to battering. ${ }^{156}$ Criminal interventions coupled with assistance

and Wife Abuse, 44 J. Marriage \& Fam. 277, 280 (1982) (finding objective marital dependency, as measured by wives' unemployment, presence in home of children under five years of age, and whether husband earned $75 \%$ or more of couple's income, was correlated with more severe abuse); Jody Raphael, Domestic Violence and Welfare Receipt: The Unexplored Barrier to Employment, 3 Geo. J. Fighting Poverty 29, 30-31 (1995) (describing the manner in which women receiving welfare must rely on male partners, some of whom are controlling and abusive and sabotage women's attempts at economic self-sufficiency).

153. See Barbara Hart, Battered Women and the Justice System, in Do Arrests and Restraining Orders Work?, supra note 23, at 98 (describing the many reasons that battered women may decide not to cooperate with prosecution).

154. Id.

155. Goodman et al., supra note 31, at 437 (1999) (finding that women who had family or friends who could assist them with childcare, transportation, emergency loans, and help with other chores, were more likely to cooperate with prosecution than were women who did not have these informal sources of tangible support). The researchers found no significant relationship between women's cooperation with prosecution and the levels of emotional support available to victims, the level of institutional supports available, or the women's levels of depression or emotional dependence on the batterer. Id. at 440; see also Naomi Cahn, Policing Women: Moral Arguments and the Dilemmas of Criminalization, 49 DePaul L. Rev. 817, 828 (2000) ("[b]ecause criminalization does not address the emotional or financial obstacles faced by battered women, criminalization alone is insufficient.").

156. See supra note 72 and text accompanying. The importance of material 
directed at alleviating the sources of women's vulnerability are likely to be more effective. Without this assistance, mandatory policies are likely to be harmful.

Feminist law reformers seek to recognize and oppose the power of batterers to control and harm women. Feminist proponents of mandatory policies recognize the coercive control exercised by battering men and the way in which that control pervades every aspect of women's lives. ${ }^{157}$ The challenge for feminist law making is to give simultaneous attention to the coercive power of the state. The state's power is shaped by women's structural inequalities and by pervasive ideologies that normalize state intervention in the lives of poor women.

\section{Controlling THE STAte: The ORganizing DILEMMA}

[W]e have moved beyond simple rejection of the state or a simple assumption that the state can solve the problem [of domestic violence.] So should we move beyond uncritical engagement with the state, particularly in the criminal context, and toward more critical theoretical and practical analysis? ${ }^{158}$

In this section, I examine the concern that the absence of mandatory policies will result in a return to police and

and social resources is apparent in one of the stories Hanna relates in support of no-drop prosecution policies. Hanna describes the circumstances of a woman suffering from AIDS. See Hanna, supra note 20, at 1874. The woman objected to prosecution of her abusive partner because she did not want to lose her only ally, even though he beat her. Id. Hanna agreed to drop charges, but seems to believe that that this was a mistake. Id. It is not clear that this woman would have been better served if Hanna had refused to drop the charges, but it does seem clear that a referral to services and support groups for persons with AIDS or assistance with material resources might have made a difference in this woman's victimization.

157. See Stark, supra note 23, at 121 (describing the manner in which "supports for male authority ... merge with the batterer's pattern of control" giving "a particular man far more power in the eyes of his mate than an outsider without expert knowledge of the situation can perceive.").

158. Schneider, supra note 3, at 198. 
prosecutor practices that ignore domestic violence cases. ${ }^{169}$ As Evan Stark argues, while "it is hard to predict whether one's welfare will be helped or hindered in any given encounter [with the police],"160 the political action that surrounds the adoption of mandatory arrest policies "alter[s] the odds favoring a positive [police] response to male violence."161 The enactment of mandatory policies, particularly mandatory arrest, may be a particularly wellsuited goal for feminist organizing. Mandatory arrest provides a bright-line standard for police behavior, which makes it easier for battered women's advocates to hold police accountable when they fail adequately to protect battered women. ${ }^{162}$ Additionally, mandatory policies that are the result of feminist activism may result in agreements that place battered women's advocates within the courts and police stations on a regular basis, ${ }^{163}$ thus providing an ongoing institutional voice for the concerns of battered women.

The concern that the absence of mandatory policies will result in further police minimization or maltreatment is well grounded. The most common complaint of battered women regarding police response is that the police do not

159. For example, in response to Mills's rejection of mandatory policies, Stark writes:

Mills insists she does not favor returning to the discretionary policies of the past. But what other consequence could result if mandated arrest and aggressive prosecution were eliminated?... I am not yet ready to trust the system to support the values Mills and I share without the administrative accountability that policy directives provide.

Evan Stark, Mandated State Interventions: Evan Stark's Response, 6 Domestic Violence Rep. 1, 15 (2000).

160. See Stark, supra note 23 , at 117.

161. Id.

162. Id. Cf. Bruce J. Winick, Applying the Law Therapeutically in Domestic Violence Cases, 69 UMKC L. Rev. 33, 82 (2000) (whether or not repeal of mandatory arrest rules would result in failure of police to take domestic violence seriously is an empirical question, but given current changes in police behavior, this outcome is unlikely).

163. Stark, supra note 23 , at 128 (the work to control police response "provides a rationale for a regular shelter presence in the courts, and lays an empirical basis that shelters can exploit for custodial orders, orders of protection, and expanded services."). 
do enough. ${ }^{164}$ Women complain that unless they are seriously injured, police underestimate their danger and treat them with disrespect. ${ }^{165}$ In fact, the strongest negative ratings of victim satisfaction with police response often come from those women who desired a harsher response. ${ }^{166}$ One study finds that these victims are the least likely to call the police for subsequent violent incidents. ${ }^{167}$

Ensuring that the state responds to battered women is critical, but it is not clear that mandatory policies are the only or best manner in which to control police and prosecution response. First, policy alternatives need not be confined to a choice between mandates to arrest and prosecute, on the one hand, and unfettered official discretion, on the other. Nor is it necessarily true that police options are limited to arrest/not arrest or that prosecutor choices are limited to prosecute/not prosecute. In fact, current "soft" no-drop prosecution policies suggest the possibilities of more flexible standards. ${ }^{168}$ Soft no-drop policies allow victims to choose to drop charges under certain specified conditions, such as watching a domestic violence video, speaking to a domestic violence counselor, or appearing before a judge to explain their reasons for dropping. ${ }^{169}$ Police response can also be more flexible, while

164. See, e.g., New York Evaluation of Mandatory Arrest Provisions, supra note 123 , at 61 (victims who were dissatisfied with police response felt that they "were not treated with respect, that the police refused to investigate the crime and that the crimes were undercharged given the gravity of the conduct and the risks posed to the victims.").

165. Id.

166. See Buzawa et al., supra note 56 , at 266 (finding that all five victims who expressed dissatisfaction with police response wanted more aggressive response).

167. Id.

168. See Hanna, supra note 20, at 1863 (describing "hard" and "soft" no-drop policies). A number of feminist activists argue for placing victim protection ahead of prosecution policy; see also Hart, supra note 153, at 110 ("[i]n those instances where termination of the prosecution is critical to protect victims, the public posture should not preclude such prosecutorial discretion.").

169. Angela Corsilles, No-Drop Policies in the Prosecution of Domestic Violence Cases: Guarantee to Action or Dangerous Solution?, 63 Fordham L. Rev. 853, 86062 (1994) (in some jurisdictions a special domestic violence unit composed of the chief prosecutor, paralegals, and victim advocates must approve any dismissal of charges; in other jurisdictions, the victim may drop charges only in certain 
still incorporating a standard for police conduct. For example, Lawrence Sherman proposes that police be subject to "mandatory action" policies that require that they choose from a list of options including:

offering to transport the victim to a shelter, taking the suspect or victim to a detoxification treatment center, allowing the victim to decide if an immediate arrest should be made, [and] mobilizing the victim's social networks to provide short-term protection. ${ }^{170}$

A second difficulty with reliance on mandatory policies to ensure police and prosecutorial response is that the effectiveness of these policies depends, in large part, on the existence of an effective battered women's organization. But mandatory policies are sometimes adopted for reasons unrelated to feminist organizing, such as the desire to appease "tough on crime" constituencies while also currying favor with female voters, ${ }^{171}$ or the desire to be

circumstances, for example where the accused has no prior convictions; others require that the victim be advised that her risk of victimization is increased if she drops charges, that she attend a support group, or that she watch a video on domestic violence before being allowed to drop charges).

170. Lawrence W. Sherman, Policing Domestic Violence: Experiments and Dilemmas 255-56 (1992). A number of scholars have argued for modified police discretion, which would require arrest only under certain conditions. See, e.g., Peter Margulies, Surviving the State: Transition, Discretion, and Membership in Domestic Violence Law (forthcoming 2001) (manuscript at 48-53, on file with author). Margulies argues that if any of the following are true of the abuser, arrest, prosecution, and incarceration are justified, even if the victim objects: a history of significant violence towards third parties as well as intimates; commission of severe violence; commission of chronic violence. However, if the victim believes that arrest will increase her danger, police should not arrest unless they have enough evidence, absent her testimony, to have a realistic chance of conviction and incarceration. Id.; see also Winick, supra note 162, at 80-84 (arguing for a presumptive arrest policy which allows officers to take victim's desires as well as the risk of batterer recidivism into consideration in determining whether to arrest); Buzawa et al., supra note 56, at 25-26 (recommending that with low risk, first time, or "multi-year latency" batterers, the victim's preference regarding arrest and prosecution should control, while high risk batterers should be arrested and subject to "long term, strictly supervised periods of probation and escalating penalties" for repeat offenses and violations of restraining orders).

171. See Sparks, supra note 1 , at 44 ("Merely adopting a pro-arrest policy alone 
eligible for federal funds that require that state grantees adopt a pro-arrest policy. ${ }^{172}$

A number of battered women's advocates believe that mandatory policies should be adopted only when the policies are a part of a "coordinated community response" that includes significant advocacy and services for battered women. ${ }^{173}$ Melanie Shepard, for example, argues that the following essential services for battered women must be in place before engaging in "institutional reform": emergency housing, legal advocacy, support groups for battered women, and financial resources for battered women. ${ }^{174}$ "[W]ithout... [these] essential services, battered women may be placed in greater danger when the criminal justice system responds to the offender's violence."175

Even the availability of services for battered women may not be adequate to ensure that advocates engage in ongoing monitoring of the criminal justice system. Battered women's advocates should be "the stewards of [the service and legal] infrastructure as they direct, guide, and support battered women while confronting and challenging obstacles to their safety."176 Many advocacy programs are simply not prepared to take on this monitoring role. ${ }^{177}$ Yet,

may signal a primary focus on law enforcement, rather than community involvement and empowerment for battered women, as the 'solution' to domestic violence.").

172. See supra note 35 (describing federal funding mandates).

173. See, e.g., Melanie F. Shepard, Advocacy for Battered Women: Implications for a Coordinated Community Response, in Coordinating Community Responses to Domestic Violence: Lessons from Duluth and Beyond, supra note 85, at 115 ("Iclommunity intervention projects that focus on institutional reform should not be initiated without an infrastructure of community services in place to provide support to battered women").

174. Id.

175. Id. at 116.

176. Shepard, supra note 173, at 115; see also Denise Gamache \& Mary Asmus, Enhancing Networking Among Service Providers: Elements of Successful Coordination Strategies, in Coordinating Community Responses to Domestic Violence: Lessons from Duluth and Beyond, supra note 85, at 65, 79 (emphasizing the prominent role of women's advocates in ensuring that a "coordinated community response" program assists battered women).

177. Gamache \& Asmus, supra note 176, at 79 ("not all advocacy programs... are prepared to assume the key role that is necessary for coordination to be effective."). 
the availability of such advocacy may be a critical determinant in the quality of battered women's experiences with mandatory policies. Advocates act in two important roles: as institutional reformers-monitoring police, prosecutor, and judicial responses to domestic violence; and, as advocates for individual women. ${ }^{178}$ They often act to soften the effects of mandatory policies when those policies threaten to harm individual women. As one advocate notes, "[t]he criminal justice process does not always effectively address the individual needs of women and does not work well for many[,]" thus, advocates frequently find themselves "hav[ing] argued for policy reforms (e.g., prosecution of cases) only to turn around and ask for exceptions for individual battered women."179

If battered women's advocates are to play such a critical role in the implementation of mandatory policies, they must adequately represent the range of interests of women who are battered. The existence of a local battered women's organization does not necessarily insure this will be the case. This is true for several reasons. First, domestic violence service providers do not necessarily share a unified vision of their work. Mental health professionals who are trained to focus on individual behavioral changes,

178. These dual roles can create some tension. See, e.g., id. at 120 . An advocate states:

The uncomfortable part is that I am caught between advocating for women and being part of a system. That's the difficult part for me because I'm doing both things at the same time. I'm on call to keep me focused on the women, yet I work for an agency that creates and helps to change the institutional practices.

Id.

179. Shepard, supra note 173 , at 120 (quoting an battered women's advocate). Hanna argues that this dual position is untenable: "One difficulty of discussing mandated participation within a feminist framework is that we are often left in the untenable position of arguing that the state should only intervene in women's lives when it is 'good' for them and stay out when it is 'bad."); Hanna, supra note 20 , at 1872. Hanna understands this dual position as representative of "mixed messages" because the advocacy community wants prosecutors to take domestic violence cases seriously, "[but] they are unwilling to acknowledge the practical dilemmas posed when a jurisdiction pursues an aggressive strategy." Cheryl Hanna, The Paradox of Hope: The Crime and Punishment of Domestic Violence, 39 Wm. \& Mary L. Rev. 1505, 1552 (1998). 
rather than on community activism and political change may operate battered women's services. ${ }^{180}$ Further, domestic violence interventions are frequently the result of compromises between the competing goals of stakeholder organizations and professionals, each of whom brings a somewhat different agenda and different understanding of the dynamics of domestic violence. ${ }^{181}$

In addition, a local battered women's organization may not be representative of all battered women if the interests of women of color, ethnic minorities, and other marginalized women are not well represented. ${ }^{182}$ Shelters

180. See Schechter, supra note 6, at 106-07 (professionals working with battered women minimized the need for advocacy and social change and often reject a feminist analysis of battering).

181. In some locales, the funding structure exacerbates these tensions. For example, state funds for battered women's shelters in Florida are funneled through the Department of Children and Families, the same department that responds to charges of child dependency and neglect. Since battered mothers are sometimes accused of child abuse, including "failing" to prevent child abuse committed by their violent partner or failing to prevent their children's exposure to their own abuse, see discussion supra pages 833-37, a tension exists between the mission of shelters to empower battered women and that of child protection workers. The Florida funding arrangement thus compromises the shelter's ability to advocate for battered women who are the subject of child abuse and neglect investigations. See generally interview with Dougan, supra note 124.

182. See, e.g., Jenny Rivera, Intimate Partner Violence Strategies: Models for Community Participation, 50 Me. L. Rev. 283, 295 (1998) ("Communities with disparately less power in the larger social structure are disparately represented in the coalition [against domestic violence]....”); Gloria Valencia-Weber \& Christine P. Zuni, Domestic Violence and Tribal Protection of Indigenous Women in the United States, St. John's L. Rev. 69, 130 (1995) ("Indian women and other women of color confront the same cultural insensitivity and racism at urban domestic violence shelters as they do elsewhere. These shelters can be unaware of the cultural resources which should be used to assist Indian victims of domestic violence."); Crenshaw, supra note 37, at 1262-65 (1991) (describing way in which shelters for battered women fail to meet needs of women of color); Zanita E. Fenton, Domestic Violence in Black and White: Racialized Gender Stereotypes in Gender Violence, 8 Colum. J. Gender \& L. 1, 11 (1998) (describing manner in which racial and gender based stereotypes interact in stereotypes of women's victimization); Beverly Horsburgh, Schrdegreesodinger's Cat, Eugenics, and the Compulsory Sterilization of Welfare Mothers: Deconstructing an Old/New Rhetoric and Constructing the Reproductive Right to Natality for Low-Income Women of Color, 17 Cardozo L. Rev. 531, 577 (1996) ("Strategies [against domestic violencel ... are inclined to reflect the experiences of white women" and "seldom deal with the economic and workplace discrimination issues that best women of color."); Kimberly A. Huisman, Wife Battering in Asian American 
and advocacy programs often operate with all-white or nearly all-white staff. ${ }^{\text {183 }}$ Battered women's service organizations are often unaware of, and do not meet, the particular needs of women of color..$^{184}$

A coordinated community response offers a balance between the need to create a system for controlling the state (for battered women's benefit) while protecting individual women. That balance requires a particular kind of advocacy infrastructure, however. Such an infrastructure consists of significant services for battered women as well as savvy, institutionally integrated-yet independently minded and funded-advocates for women. These advocates must simultaneously urge state actors to follow the (mandatory) rules-e.g., arrest and prosecuteand argue for exceptions to those rules when a woman is endangered by them. It is a tribute to the tenacity and creativity of the battered women's movement that this is happening anywhere-and it is! ${ }^{185}$ But this kind of independent advocacy does not represent the state of

Communities, 2 Violence Against Women 260, 267 (1996) (noting that services for battered women frequently do not have workers who are linguistically and culturally competent to assist Asian American battered women, particularly recent immigrant women); Rivera, supra note 29, at 253 (noting that shelters sometimes refuse admission to monolingual Spanish speakers and few shelters have bilingual and bicultural staff); Valli Kanuha, Domestic Violence, Racism, and the Battered Women's Movement in the United States, in Future Interventions with Battered Women and Their Families 34, 45 (Edleson \& Eisikovits eds., 1996) (arguing that the battered women's movement has failed to represent battered women who are "most at the margins," including women of color and discussing situation of native Hawaiian women, in particular).

183. See Denise A. Donnelly et al., Provision and Exclusion: The Dual Face of Services to Battered Women in Three Deep South States, 5 Violence Against Women 710, 722-25 (1999) (interviews with executive directors of forty-four agencies for battered women found that women of color were frequently underserved and some shelter directors offered racial stereotypes as explanations for the low numbers of women of color shelter residents); Rivera, supra note 29, at 295 ("Communities with disparately less power in the larger social structure are disparately represented in the coalition [against domestic violence] ....").

184. See, e.g., Valencia-Weber \& Zuni, supra note 182.

185. See Ellen L. Pence \& Melanie F. Shepard, An Introduction: Developing a Coordinated Community Response, in Coordinating Community Responses to Domestic Violence: Lessons from Duluth and Beyond, supra note 85 (describing the program in Duluth, Minnesota which has served as a model for programs throughout the U.S., as well as other countries). 
affairs in many areas. ${ }^{186}$

Thus, feminist law reformers are faced with a dilemma. Mandatory policies can provide some measure of control over police and prosecutorial response, but such policies may also increase the state's control of women. This risk of increased state control is particularly true for those women who are otherwise most vulnerable to state control: poor women, particularly poor women of color, and women who are engaged in minor crimes, many of which are directly related to battering. The ability of mandatory policies to control state action is related to the political strength of the battered women's movement in a given locale and the available services for battered women, but mandatory policies are implemented in jurisdictions with weak or non-existent advocacy communities. Activists who support mandatory policies frequently presume that battered women's advocates will play an ongoing monitoring role and will mediate the effects of mandatory policies in circumstances where women are endangered, yet there is no guarantee that such advocacy is available or that the advocacy community will adequately represent the interests of all women.

\section{CONTROLLING THE MESSAGE: THE DILEMMA OF EXPRESSING SOCIAL DISAPPROVAI}

Perhaps the most common argument for mandatory policies is that they "send a message" of intolerance for domestic violence. ${ }^{187}$ The message argument captures two

186. It may be particularly difficult to create such systems in large metropolitan areas. See Robyn Holder, Pick N Mix or Replication: The Politics and Process of Adaptation, in Coordinating Community Responses to Domestic Violence: Lessons from Duluth and Beyond, supra note 85, at 255, 269 (questioning whether the model from the Domestic Abuse Intervention Project of Duluth, Minnesota, which has served as a model for coordinated community response programs in England, New Zealand, and Australia, is adaptable to large metropolitan areas such as London).

187. See, e.g., Hoctor, note 84, at 659 (1997) ("[arrest] communicates ... that domestic violence is a crime"; "[the failure to arrest] tells the parties and others that domestic violence is a private matter and is acceptable."); Marion Wanless, Mandatory Arrest: A Step Toward Eradicating Domestic Violence, But is it 
distinct impulses regarding criminal intervention in domestic violence cases. The first is what Jean Hampton and other retributivists refer to as the "expressive" justification for criminal law. ${ }^{188}$ Hampton argues that when someone commits an act of violence, the perpetrator's behavior expresses a belief in his right to subordinate the victim. ${ }^{189}$ The message of the offender's act is that the victim is of less worth than the offender. ${ }^{190}$ Hampton argues that criminal law should reverse this message. ${ }^{191}$ Punishing the offender expresses both the victim's worth and society's moral outrage at the perpetrator's misuse of the victim. ${ }^{192}$

The second argument that strong criminalizing policies "send a message" relates to the importance of emphasizing domestic violence as a public and structural problem, rather than a private and individual problem. ${ }^{193}$ Criminal

Enough?, 1996 U. Ill. L. Rev. 533, 554 (1996) ("By enacting mandatory arrest laws states send a strong message that domestic abuse will not be tolerated. Mandatory arrest signals that domestic violence is a crime with attendant consequences."). Hanna, supra note 20, at 1889-1900 ("by penalizing criminal conduct, the criminal justice system communicates strong educational and social messages .... One of the most important ways to curb domestic violence is to ensure that abusers understand that society will not tolerate their behavior."); Corsilles, supra note 169, at 874 (no-drop prosecution policies send a message to the victim that "convey[s] . . society's assessment of the pains inflicted on her[,]" and a message to batterers "that their behavior is no longer tolerated by the state and is punishable by law.").

188. See Jean Hampton, Punishment, Feminism, and Political Identity: A Case Study in the Expressive Meaning of Law, 11 Can. J. of L. \& Jurisprudence 23 (1998).

189. Id. at 31 ("violence [against women] expresses" and helps to realize "the view that men are entitled to dominate over women.").

190. Id. at 38 ("The actions which we make criminal offenses are ones that diminish the value or dignity of the victims, either through the harm committed, or because of the nature of the action itself.").

191. Id. at 39 ('It is because these [criminal] acts 'say' something that diminishes the victims' value that we wish to inflict punishment that says something in return in order to insist on the victim's true (equal) value, and deny the wrong-doer's claim to elevation.").

192. Id. The expressive argument is built on the recognition that violence is a "tool of oppression" of women and that failure to "express any kind of condemnation of the criminal's conduct [leaves] that conduct, and its meaning, unchallenged." Id. at 36.

193. See Elizabeth M. Schneider, The Violence of Privacy, in The Public Nature of Private Violence: The Discovery of Domestic Abuse, supra note 77, at 
justice system responses to domestic violence may help to change the common belief that domestic violence is a problem of individuals and therefore of little consequence to the larger society. Concepts of family privacy result in immunizing batterers from public scrutiny and intervention. ${ }^{194}$ The reluctance of police, prosecutors, and judges to intervene in domestic violence cases can be understood as a vestige of coverture in which husbands were given the authority to govern their wives and children. ${ }^{195}$ Criminal punishment counters these conceptions of privacy by marking the violence as serious and of public concern and by "send[ing] a clear social message that battering is impermissible . . . ."196

36, 43 ("The concept of privacy encourages, reinforces, and supports violence against women. Privacy says that violence against women is immune from sanction, that it is permitted, acceptable and part of the basic fabric of American family life."); Martha Minow, Words and the Door to the Land of Change: Law, Language, and Family Violence, 43 Vand. L. Rev. 1665, 1671 ("Society is organized to permit violence in the home.... [because] [s]ociety permits such violence to go unchallenged through the isolation of families and the failure of police to respond.").

194. See Schneider, supra note 193.

195. See Isabel Marcus, Reframing 'Domestic Violence': Terrorism in the Home, in The Public Nature of Private Violence: The Discovery of Domestic Abuse, supra note 77, at 11 (arguing that coverture remains through the tolerance of domestic violence); Zanita E. Fenton, Mirrored Silence: Reflections on Judicial Complicity in Private Violence, 78 Or. L. Rev. 995 (1999).

196. See Schneider, supra note 193, at 43. As I argue elsewhere, the feminist critique that explains state reluctance to intervene in domestic violence cases as the product of patriarchal notions of family privacy is an important but inadequate description of the relationship between families and the state. See supra note 23 , at $7-8$. Race and class mark the history of that relationship and affect the quality of "privacy" that families enjoy. As Riva Siegal's history of U.S. domestic violence law demonstrates, notions of family privacy eventually gave way to class-and race-based notions of white middle-class superiority. By the end of the nineteenth century harsh penalties such as whipping were proposed for wife beaters who were characterized as "lawless or unruly men of the "dangerous classes." See Reva B. Siegel, The Rule of Love': Wife-Beating as Prerogative and Privacy, 105 Yale L.J. 2117, 2137-39 (1996). These "dangerous classes" referred primarily to African American and low-status immigrant men. Id. The massive removal of Indigenous children by the governments of Australia, the U.S., and Canada eloquently demonstrates the way in which an ideal of family privacy has little relevance for the description of relations between the state and families in subordinated communities. See generally Marlee Kline, Child Welfare Law, "Best Interests of the Child" Ideology, and First Nations, 30 Osgoode Hall L.J. 375 
In addition to countering the batterer's message of dominance and devaluation of the victim, mandatory policies may also send a message that counters more general devaluation of victims. Class, race, and ethnicity inform the manner in which a victim is determined "worthy." 197 Dorothy Roberts demonstrates, for example, that much of U.S. law with regard to procreation reflects a devaluation of Black women, as individuals, and a devaluation of their social roles as mothers. ${ }^{198}$ Women who defy gender norms, women who are "bad" or "deviant," are also treated as less worthy by criminal justice system actors. ${ }^{199}$

The devaluation of poor people of color is apparent in the twin problems of aggressive policing and under-policing that plague poor minority neighborhoods. ${ }^{200}$ Hyper-

(1992) (describing the removal of First Nations children by the Canadian government); Human Rights and Equal Opportunity Commission, Australia, Bringing Them Home: Report of the National Inquiry into the Separation of Aboriginal and Torres Strait Islander Children from Their Families (1997) (describing the removal of Aboriginal children by the Australian government); Indian Child Welfare Act of 1978, 25 U.S.C. $\S 1911$ et seq. (2000) (legislation to correct the removal of Native American children by U.S. government).

197. See McCleskey v. Kemp, 481 U.S. 279, 287 (1987) (defendant relied on a study (the Baldus study) of 2,000 murder cases in Georgia finding that "after taking account of 39 nonracial variables, defendants charged with killing white victims were 4.3 times as likely to receive a death sentence as defendants charged with killing blacks."). The current language of crime control-referring to "urban jungles," and references to the animalistic qualities of criminals, reflects a devaluation of the lives of those deemed "criminal." Further, this imagery is often explicitly racist, thus simultaneously devaluing the lives of African Americans and all of those convicted of crimes. See Angela P. Harris, Gender, Violence, Race, and Criminal Justice, 52 Stan. L .Rev. 777, 800 (2000).

198. See generally Dorothy E. Roberts, Killing the Black Body: Race, Reproduction, and the Meaning of Liberty (1997).

199. See Kathleen J. Ferraro, The Legal Response to Woman Battering in the United States, in Women Policing, and Male Violence International Perspectives 155 (Jalna Hanmer et al. eds., 1989) (stating that police respond differently to "deviants" than to "normals" and often see poor women and intoxicated women as former); see generally Michelle S. Jacobs, Prostitutes, Drug Users, and Thieves: The Invisible Women in the Campaign to End Violence Against Women, 8 Temp. Pol. \& Civ. Rts. L. Rev. 459 (1998) (criticizing the failure of feminist theorists to examine violence in the lives of women who engage in prostitution, drug user, and other criminal behavior, in part because of feminist theory reliance on the trope of the "good" victim).

200. See Angela P. Harris, Criminal Justice as Environmental Justice, $1 \mathrm{~J}$. 
aggressive policing is partially to blame for the disproportionate numbers of African American, Latino, and indigenous men in prison. ${ }^{201}$ Devaluation of African American women, Latinas, and indigenous women is apparent in the police failure to respond to domestic violence calls from these women. ${ }^{202}$ Mandatory policies which require police to respond and to arrest may counter the message of devaluation of poor women of color.

The difficulty with the expressive argument, however, is that law enforcement interventions carry a set of social meanings that are often contradictory, highly contextual, and related as much or more to police attitudes and policing processes ${ }^{203}$ than to the substance of statutes or the operation of courts. Criminal justice intervention will have different meanings for men and women who are members of communities subordinated by race, class, or ethnicity.

Gender Race \& Just. 1, 20-21 (1997) (historically the problem with policing in "poverty-stricken African American communities" was one of police disinterest in black-on-black crime; currently, "poor policing frequently takes the form of indiscriminate, violent, and racist intrusions ... provoking fear, resentment, and contempt among the population ostensibly to be protected.").

201. Much of this is the result of "war on drugs" policing. See Tracey L. Meares, Social Organization and Drug Law Enforcement, 35 Am. Crim. L. Rev. 191,213 (1998) ("the racial asymmetry in drug incarcerations . . . is the inevitable consequence of the current drug law enforcement strategy."). The incarceration rates of African American men have increased dramatically as a result of drug policy, see generally Tonry, supra note 146 , as have the incarceration rates of African American women, see Bush-Baskette, supra note 145.

202. See, e.g., Rivera, supra note 29 , at 247 ("There may be a sense among police officers that violent behavior is commonplace and acceptable within the Latino community, and that both men and women expect Latinos to react physically in situations of domestic conflict."); Linda L. Ammons, Mules, Madonna's, Babies, Bath Water, Racial Imagery and Stereotypes: The AfricanAmerican Woman and the Battered Woman Syndrome, 1995 Wis. L. Rev. 1003, 1018 ("Black women ... must overcome the [police] presumption that their race predisposes them to engage in and enjoy violence.").

203. See Julie Stubbs, 'Communitarian' Conferencing and Violence Against Women: A Cautionary Note, in Wife Assault and the Canadian Criminal Justice System: Issues and Policies (Mariana Valverde et al. eds., 1995) 260, 262 ("The outcome of policing, and of criminal justice intervention more generally is likely to be varied, perhaps contradictory, and in part determined by context"); Raymond Paternoster et al., Do Fair Procedures Matter? The Effect of Procedural Justice on Spouse Assault, 31 Law \& Soc'y Rev. 163 (1997) (a belief in procedural fairnesse.g., that they were treated fairly by the police-had an inhibiting effect on recidivism for men arrested for domestic violence). 
This is true both in symbolic terms, of the nature Hampton identifies, as well as in concrete terms.

Evidence suggests that men of color are arrested for domestic violence in disproportionate numbers, ${ }^{204}$ but even if that were not the case, arrest may have disproportionately negative effects and carry a disproportionately negative meaning for men of color and indigenous men. These negative effects may increase the likelihood of batterer recidivism. Disproportionately negative effects for men of color and indigenous men occur in at least three ways. First, many men of color are more likely to experience harsher treatment for a domestic violence misdemeanor arrest because they are more likely to have a record of prior arrests. ${ }^{205}$ This is the result, in part, of discriminatory police enforcement and the surveillance and crime control behavior of many urban police forces. ${ }^{206}$ The result is that these men are less likely to be eligible for diversion or probation and more likely to

204. See discussion, supra notes 31,32 and text accompanying.

205. See Jerome G. Miller, From Social Safety Net to Dragnet: African American Males in the Criminal Justice System, 51 Wash. \& Lee L. Rev. 479, 487-88 (1994) (citing 1990 research by the Sentencing Project that finds that "on an average day in the United States, one of every four African American men age twenty to twenty-nine was either in prison or jail or on probation or on parole"; contrary to stereotype, most of the charges brought against young African American men are for non-violent crimes); see also Lawrence A. Greenfeld \& Steven K. Smith, U.S. Dep't of Justice, American Indians and Crime 26 (1999) (over $4 \%$ of the American Indian population is under correctional control, compared to $2 \%$ of white adults, $9.8 \%$ of African American adults, and less than $0.5 \%$ of Asian adults; American Indians under correctional control are much more likely to be incarcerated (46\%), than are others who are under correctional control).

206. See generally Meares, supra note 201, at 213 (describing the harmful effects on poor minority communities of "get tough" policing policies); Tonry, supra note 146 (the "war on drugs" led to "a tactical focus on disadvantaged minority neighborhoods" where arrests were easier to make and where trade in the drugs primarily targeted by the War-cocaine and crack-was readily apparent.). Increasingly, a conviction for domestic violence can result in what Peter Margulies refers to as "sanctioning cascades" in which mandatory arrest and prosecution trigger secondary enforcement measures such as immigration law provisions that make domestic violence conviction a grounds for deportation or requirements of notification to employers. See Margulies, supra note 170, at 45; see also Coker, supra note 14, at 1016 (describing the harmful effects of such policies as employer notification). 
receive enhanced sentences for repeat offenders. ${ }^{207}$ Second, a batterer's prior history with law enforcement is likely to effect the meaning he derives from a domestic violence arrest. If the arrest marks yet "another stigmatic encounter with the justice system," 208 the arrest may convey disrespect for him, rather than convey respect for the victim.

The third way in which mandatory policies may have disproportionately negative meanings for men of color and indigenous men regards the manner in which marginalized men and police sometimes construct masculinities. When men batter their female partner, it is often a means of reasserting control and dominance. ${ }^{209}$ "[M]en use violence or the threat of violence as an affirmative way of proving individual or collective masculinity, or in desperation when they perceive their masculine self-identity to be under attack."210 Angela Harris describes the manner in which "[m]en denied access to [the dominant form of masculinity in America]-because they are working class and take orders rather than give them, or because they lack the education and training to exhibit technological prowessoften resort to 'hypermasculinity' (the exaggerated exhibition of physical strength and personal aggression) in an attempt to gain social status."211 "Hypermasculinity" may characterize both the response of police officers as well as that of "offenders" 12 resulting in a "mutually

207. Domestic violence diversion is usually available only for those with no criminal record and the diversion requires completion of a batterer's treatment program and no further arrest. See, e.g., Linda Dakis \& Lauren Lazarus, Attacking the Crime of Domestic Violence: How Dade County is Protecting the Victim and Punishing the Perpetrator, 19-SPG Fam. Advoc. 46, 49 (1997).

208. John Braithwaite \& Kathleen Daly, Masculinities, Violence and Communitarian Control, in Just Boys Doing Business? Men, Masculinities, and Crime 189, 199 (Tim Newburn \& Elizabeth A. Stanko eds., 1994) (describing a pyramid of increasing sanctions against batterers, including community conferencing).

209. See Coker, supra note 99, at 40 ("Batterers ... use the political and economic vulnerability of women to reinforce their power and dominance over particular women.").

210. Harris, supra note 197 , at 781 .

211. Id. at 784.

212. Id. at 793 . 
antagonistic yet interdependent relationship .... [u]nited in a kind of masculine community." 213 When police intervention reenacts a masculine display-violence met with violence-it is unlikely to curb battering. This suggests that the message of mandatory policies sometimes has little to do with expressing the moral worth of the victim and more to do with expressing state control over men in subordinated communities.

The meaning that batterers attach to mandatory policies may be an important variable in the likelihood that they will continue their violence. Sherman's findings that arrest had an escalating effect on the violence of unemployed men ${ }^{214}$ - that is, unemployed men arrested for domestic violence were more likely to commit further acts of violence then were unemployed men who were warned and not arrested-may be explained by the different meanings that criminal justice intervention holds for offenders. Elizabeth Marciniak's review of NIJ arrest study data in Milwaukee suggests such a possibility. ${ }^{\mathbf{2 1 5}}$ Marciniak found that residence in the most marginalized neighborhoods was a stronger predictor of increased violence following arrest than was the unemployment status of those arrested. ${ }^{216}$ These findings are consistent with the work of Tracey Meares. ${ }^{217}$ Meares demonstrates that the social disorganization characteristic of some inner city neighborhoods relates to the level of crime in those neighborhoods. ${ }^{218}$ As Meares explains, "the structure of the community in which an individual lives interacts in important ways to either facilitate or retard the

213. Id. at 793. Harris is describing members criminal street gangs and police officers.

214. See Sherman, supra note 42.

215. See Marciniak, supra note 43 , at 74 (analyzing Milwaukee data, which found that arrestees living in census tracts with high levels of female headed households, families receiving welfare, poverty, high divorce rate, and high unemployment had higher domestic violence recidivism rates post-arrest).

216. Id.

217. See, e.g., Meares, supra note 201, at 213-17; Tracey L. Meares, Charting Race and Class Differences in Attitudes Toward Drug Legalization and Law Enforcement: Lessons for Federal Criminal Law, 1 Buff. Crim. L. Rev 137 (1997).

218. See generally Meares, supra note 201; Meares, supra note 217. 
individual's criminal . . behavior."219

Mandatory policies may have a disproportionately negative impact on communities of color, as well as on individual men who batter. For example, the hypersegregation ${ }^{220}$ of many cities means that it is much more likely that a significant number of African American men arrested will reside in the same neighborhood than is true for whites who are arrested. When large numbers of men are arrested in a given neighborhood, other residents of the neighborhood may be less likely to believe in the legitimacy of law enforcement. ${ }^{221}$ The meaning a battered woman's community attaches to criminal intervention against domestic violence is likely to affect her own assessment of the policy and its usefulness. If her community believes that calling the police for domestic violence is disloyal, ${ }^{222}$ for example, not only may this assessment effect her own values, but it is likely to reflect the kind of assistance she will receive from her community if she rejects their assessment.

In addition, the meaning of mandatory policies for battered women may depend, in part, on the quality of the interaction between victims and police officers. Interviews with battered women find that their satisfaction with police response often depends on the demeanor of the officers. ${ }^{223}$

219. Meares, supra note 201 , at 191.

220. See Douglas S. Massey, Getting Away with Murder: Segregation and Violent Crime in Urban America, 143 U. Pa. L. Rev. 1203, 1219 (1995) (asserting that hyper-segregation and rising black poverty creates neighborhoods with "street orientation," meaning "a social world characterized by high levels of interpersonal hostility and aggression.").

221. See Meares, supra note 201, at 213-17 (racial asymmetry in drug incarcerations discourages law-abiding citizens from cooperating with the police because the policy stigmatizes all African Americans as "criminal" which, in turn, promotes distrust of law enforcement, and because of the belief in "linked fate.").

222. See Richie, supra note 142, at 62 (describing the ways in which the sense of racial solidarity for some African American women creates a conflict with their needs as battered women); Rivera, supra note 29, at 248 ("Latinas face the precarious, often untenable situation of the 'double bind'- empowerment through the disempowerment of a male member of the community. The internal conflict and external pressures to cast police officials as outsiders, hostile to the community, frustrates the development of the Latinas' empowerment.").

223. See New York Evaluation of Mandatory Arrest Provisions, supra note 123, 
Victims may experience mandatory policies in ways that affirm their moral worth or in ways that do not.

\section{CONCLUSION}

Protecting battered women requires that the criminal justice system respond when women call. It also requires policies that allow women to leverage their personal and public resources, including criminal justice resources, in their efforts to stop battering.

This requires that battered women have some measure of control over the deployment of criminal interventions. But "choice" is not meaningful if women do not have adequate material resources or if they cannot gain some protection against the coercion of both the batterer and the state.

Poor women are subject to a dual vulnerability: the private coercion ${ }^{224}$ and violence of abusive men and the public coercion and violence of the state. ${ }^{25}$ When battered

at 53 (interviews with battered women demonstrates that "[o]ne of the most powerful factors that seemed to determine victim satisfaction with the police was the manner in which he police treated the victim."). This is consistent with the findings of researchers regarding procedural justice. See, e.g., Paternoster et al., supra note 203, at 176-82 (reporting lower recidivism for those offenders who received higher measures of procedural fairness and measuring of procedural fairness to include not handcuffing the accused, not using physical force in the arrest, and the police taking the time to listen to both the offender and the victim); see generally Tom $R$. Tyler, Multiculturalism and the Willingness of Citizens to Defer to Law and to Legal Authorities, 25 Law \& Soc. Inquiry 983, 1000,1009 (2000) (people are more willing to defer to legal authority when they perceive that they were treated fairly, but this may be less true for those who strongly identify with a subgroup).

224. Poor women are also especially vulnerable to the "private" coercion and violence in their work. See generally Regina Austin, Employer Abuse, Worker Resistance, and the Tort of Intentional Infliction of Emotional Distress, 41 Stan. L. Rev. 1 (1988) (describing worker mistreatment, most of which is treated by courts as not severe or outrageous enough to give rise to tort damages).

225. As a result of this dual vulnerability, the benefits of law reform may be particularly difficult to sustain for poor women. Consider the example of child custody laws. A number of states have adopted statutory presumptions against granting custody to a batterer. See supra note 122. The result is to change dramatically the nature of battered women's bargaining with their spouse at divorce. However, in adopting these laws, legislatures became convinced of the harms children suffer as a result of witnessing domestic violence. This, then, has 
women's advocates negotiate with the state, ${ }^{226}$ the challenge is to develop strategies that ensure a positive state response, while limiting the risk that these interventions will result in increased state control of women.

How might we diminish the risk that increasing state intervention against domestic violence will increase state control of women? First, we must organize for more material assistance for battered women. Crime control policies are costly, but lawmakers continue to be willing to allocate funds for purposes that sound like "fighting crime." We must begin to articulate that economic justice for women and children is part of domestic violence prevention. ${ }^{27}$ Bundling services within crime control programs does not adequately address this need. This is true both because of the limitations of the programs and because many battered women do not come to the attention of the criminal justice system. ${ }^{228}$ A focus on economic justice requires that battered women's advocates work to strengthen coalitions with activists and organizations that attend to the broader picture of violence against women in

become a rationale for increased intervention in battered women's lives through state child protection agencies. See discussion, supra pages 833-37. Poor women and women of color are far more likely to be the subject of these child abuse and neglect allegations. Id. I do not believe that feminist efforts to demonstrate the harms to children of witnessing battering caused this result. Rather, this increase in state control and surveillance grows from the same "governing through crime" trend, see Simon, supra note 8, that has engendered efforts to treat drug use during pregnancy as child abuse, see Roberts, supra note 198 , at 150-201, and to respond to social problems such as school truancy with punitive criminal sanctions against parents, see Simon, supra note 10. The discourse regarding harms to children from witnessing abuse provides a convenient rationale for the extension of a well-established trend.

226. See Cynthia Daniels, in Feminists Negotiate the State, supra note 1, at 87 ("In their efforts to protect and empower women... feminists constantly negotiate the terms for defining, studying, and intervening in domestic violence as they interact with the many facets of the state and with the public.").

227. Id. at 90 ("Domestic violence policy must also be linked to issues of central concern to poor communities, including employment and welfare policies and police and criminal justice issues.").

228. See, e.g., Holder, supra note 186, at 269 (citing research in Australia finding that few women who experience abuse seek help from the criminal justice system). 
inner cities and the broader picture of women's economic status. $^{229}$

Second, we must recognize that universal policies are unlikely to be successful. Rather, effective policies must derive from local struggles and local organizing efforts.

Third, we must explore alternatives to mandatory policies for establishing control of the state's response to domestic violence. For example, elsewhere, I suggest the establishment of domestic violence citizen review panels ${ }^{230}$ that would evaluate police response to domestic violence calls and hear complaints from individuals regarding inadequate responses. ${ }^{231}$

Finally, in developing anti-domestic violence strategies, we must attend to the coercive power of the state, as well as the coercive power of battering men.

229. See Naranch, supra note 2, at 93; see also Joan Meier, Domestic Violence, Character, and Social Change in the Welfare Reform Debate, J.L. \& Pol'y, 205, 215, Apr. 1997 (discussing the problems and potential of alliance work between poverty lawyers and battered women's lawyers); see generally Raphael, supra note 152.

230. See Coker, supra note 14, at 1051-52.

231. Id. Peter Margulies suggests something similar in which assessment panels consisting of 'representatives from survivors' self-help groups; social workers; academicians focusing on domestic violence; and representatives of law enforcement agencies" would listen to presentations from "survivors and abusers, ... a arresting officers, prosecutors, and clinicians about common themes in their experiences." Margulies, supra note 170, at 61. 